\title{
Additive Manufacturing of Customized Metallic Orthopedic Implants: Materials, Structures, and Surface Modifications
}

\author{
Long Bai ${ }^{1, * \mathbb{D}}$, Cheng Gong ${ }^{1}$, Xiaohong Chen ${ }^{1}$, Yuanxi Sun ${ }^{1} \mathbb{D}$, Junfang Zhang ${ }^{1}$, Lecai Cai ${ }^{2}$, \\ Shengyan $\mathrm{Zhu}^{2}$ and Sheng Quan $\mathrm{Xie}^{2,3}$ \\ 1 State Key Laboratory of Mechanical Transmissions, Chongqing University, Chongqing 400044, China; \\ gongcheng@cqu.edu.cn (C.G.); chenxh@cqu.edu.cn (X.C.); sunyuanxi@cqu.edu.cn (Y.S.); \\ 20160702032@cqu.edu.cn (J.Z.) \\ 2 Sanjiang Research Institute of Artificial Intelligence and Robotics, Yibin University, Yibin 644000, China; \\ ybxyclc@163.com (L.C.); lovely_pig0119@163.com (S.Z.); S.Q.Xie@leeds.ac.uk (S.Q.X.) \\ 3 School of Electronic and Electrical Engineering, University of Leeds, Leeds LS2 9JT, UK \\ * Correspondence: bailong@cqu.edu.cn
}

Received: 2 August 2019; Accepted: 9 September 2019; Published: 12 September 2019

\begin{abstract}
Metals have been used for orthopedic implants for a long time due to their excellent mechanical properties. With the rapid development of additive manufacturing (AM) technology, studying customized implants with complex microstructures for patients has become a trend of various bone defect repair. A superior customized implant should have good biocompatibility and mechanical properties matching the defect bone. To meet the performance requirements of implants, this paper introduces the biomedical metallic materials currently applied to orthopedic implants from the design to manufacture, elaborates the structure design and surface modification of the orthopedic implant. By selecting the appropriate implant material and processing method, optimizing the implant structure and modifying the surface can ensure the performance requirements of the implant. Finally, this paper discusses the future development trend of the orthopedic implant.
\end{abstract}

Keywords: orthopedic implant; bone implant; additive manufacturing; biomedical materials; cellular material; lattice material

\section{Introduction}

Various bone diseases have increased year by year due to the aging of the population and accidental damages to the bone. In order to repair bone defects, surgical treatment is used as the most fundamental treatment where various implants are needed during treatment. Among all implants, metallic implants are the most general orthopedic implants due to their superior mechanical properties and are commonly used for joint replacement, spinal fusion, and bone trauma repair, etc. However, considering the individual differences of patients, the standard type of implant manufactured by traditional processing methods cannot match the structure, the performance, and the physicochemical properties of the implant for specific bone defects, which limits the therapeutic effect and the service life of the implant [1].

In comparison with traditional processing methods, additive manufacturing (AM), a fabrication technique that manufactures parts in a gradual accumulation, can fabricate complex geometries with different materials, thereby enabling innovative designs, it also shortens the time of product development [2,3]. With the rapid development of this advanced manufacturing technology, the metallic orthopedic implant with complex structures that was impossible to manufacture using 
traditional processing methods can now be easily made. Thereby achieving personalized treatment for the patient to ensure the implant have better bone repair effect [4].

To achieve compatibility between the metallic orthopedic implant and the surrounding bone tissue, as well as to improve the bone defect repair effect, the customized implant processed by AM should meet the following requirements:

(1) Good bio-functionality. Considering the adaptability of the implant to the bone after implantation, the metal material of the implant should have adequate biocompatibility, which ensures that no rejection reaction occurs after implantation. Moreover, to further improve the biological functionality of the implant, surface modification is an effective and common way to enable the implant with desirable osseointegration properties.

(2) Suitable mechanical properties. In order to avoid the phenomenon of "stress shielding" [5], the implant requires mechanical properties such as Young's modulus and strength compatible with the bone. For solid metals, the mechanical properties are higher than the mechanical parameters of the bone, resulting in the mismatch in modulus, thereby causing the "stress shielding", which can be easily solved by using a porous metal material, the topological configuration and relative density of which can be adjusted to meet the mechanical and biological functional requirements of the implant [6-9].

(3) Appropriate morphological structure and structural processability. It is also a requisite that the shape and outer contour of the implant match the defect portion of the bone [10] to ensure a stable support function. Moreover, because of the limitations of manufacturing equipment and the influence of processing parameters, when designing customized metallic implants, the structure should be modified based on the process to ensure the machinability of the implant.

The customized metallic orthopedic implants processed by AM have drawn increasing attention owing to the favorable bone repair effect, which has been proved by the clinical applications [11-13]. However, there is not much literature on the summary of customized metallic implants; herein, we systematically outline the method of obtaining metal implants and elaborate on the structural design and surface modification of the implant. The paper is divided into five sections: introduction, materials and process methods, design approaches of implants, the development trend of the metallic implants, and summary. As shown in Figure 1, the second section of the paper introduces the metal biomaterials applied to the implant and the manufacturing method. The third section, a description of the implant design methodology, addresses the implant design flow and highlights the core technology. The core technology is mainly reflected in the structural topology design and surface modification. The fourth section discusses the problems with current implants and the further development of the implant. Finally, the article is summarized. Through the detailed introduction of the implant, the paper can open new avenues to design implants that better match natural bones.

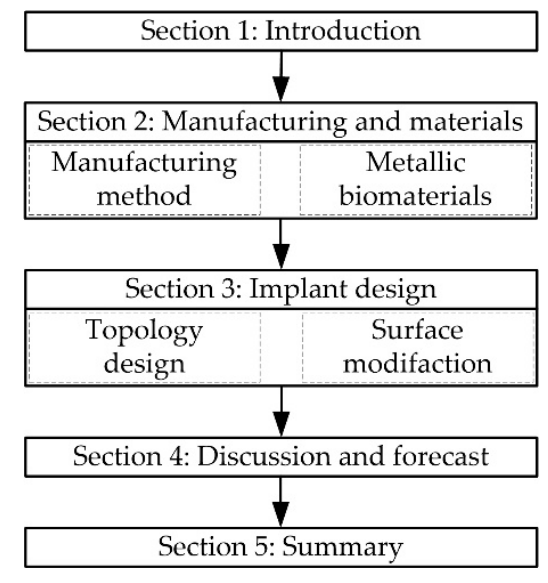

Figure 1. The structure of this review. 


\section{Additive Manufacturing Metallic Implants}

Because additive manufacturing technology can form complex parts with good resolution and shorten the manufacturing time, it is a suitable manufacturing method for orthopedic implants with an irregular and complicated structure. To meet the need of the modulus, strength, and fatigue characteristics of the implant, it can adjust the mechanical properties of the implant by changing some parameters of the processing. Nowadays, the additive manufacturing technology applied to the manufacture of metal implants is mainly powder bed fusion (PBF). The process is composed of layers and filled with powders. As shown in Figure 2. Almost all metal biomaterials can be processed by PBF as long as they can form powders. However, the size and shape of the powder particles can directly determine the efficacy of the processing method. Therefore, by selecting the better uniformity the powder size, the better manufacturing quality can be obtained [14]. Other processing parameters of the PBF, such as the layer thickness, the molding direction, the sintering energy, the scanning speed, and path, etc., will also affect the structural quality of the part $[15,16]$. The researchers have optimized these process parameters, found it can improve the surface quality and mechanical properties of the specimen [17], which guarantees the design effectiveness of the implant.

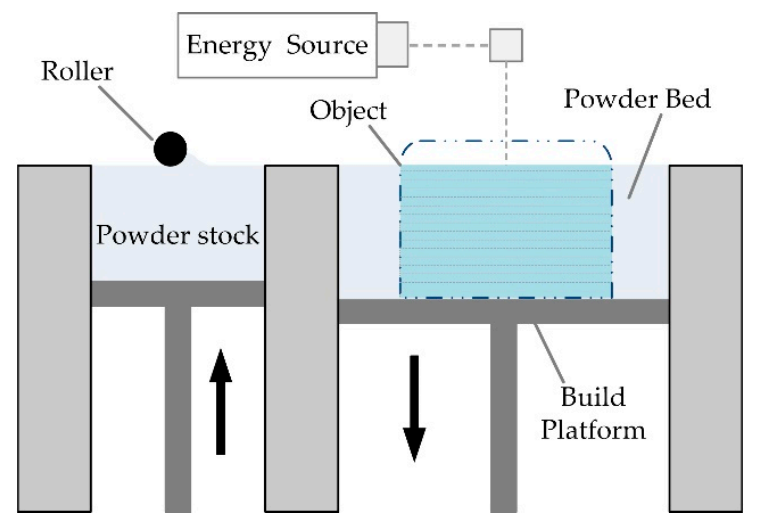

Figure 2. Schematic of Powder Bed Fusion process.

PBF technology for the implant processing includes the selective laser sintering (SLS), the selective laser melting (SLM), and the electron beam melting (EBM). As a simple processing method, SLS is free of the support structure and is adaptive to many kinds of materials. It is widely used in the processing of polymers [18-20] and metal powders [21]. Nevertheless, SLS is surpassed by SLM from two aspects. One aspect is the surface quality; the surface quality of SLM is much better than that of SLS. The other is that SLM can process a wider range of metal materials, such as pure titanium, titanium alloys, cobalt-chromium alloys, stainless steel, and other metals. Hence, SLM is more widely used in metal implants [22-24]. Another method used in metal materials processing is EBM [25,26]. It shares the same molding principle with SLM. But they use different energy sources. All methods above belong to $\mathrm{PBF}$, which can achieve precision requirements and excellent mechanical properties when fabricating complex structures. On the other hand, it is time-consuming and expensive. Apart from PBF, laser engineered net shaping (LENS) can also be used in the processing of metal implants. Bandyopadhyay et al. used LENS to process a series of metal biomaterials to get several porous implants [27], which can eliminate "stress shielding" and adapts to bones well. However, its processing accuracy is lower than that of the powder bed fusion. Thus, PBF is still the best choice for complex-structure implants fabrication.

\section{Biocompatible Metallic Materials}

The material of orthopedic implants is the key to fulfilling its various functional demands. For hard tissue replacement, it should have high enough Young's modulus and compressive strength. Thus, biocompatible metal materials have inherent advantages. Recently, there are many kinds of metals 
that can be used for orthopedic implants. Commonly used metal materials include pure titanium, titanium alloys, cobalt-chromium alloys, and stainless steel [28]. In addition, expensive metals [29,30] and degradable metals [31,32] are also suitable. ISO 13782: 1996 formulated the required characteristics of biomedical metallic materials, including chemical composition, microstructure, and mechanical properties, which provides the principle for the selection of implant materials.

\section{(1) Common metals}

Titanium and titanium alloys have the advantages of no cytotoxicity, excellent mechanical properties, and biocompatibility. Although they are more expensive than stainless steel and have poorer wear resistance than cobalt-chromium alloys, they adapt well to a bone when they are implanted into the human body [33]. Hence, they are preferred as implant metal material. The most commonly used titanium and titanium alloys are commercial pure titanium and Ti-6Al-4V alloy [34]. These materials can be used in a variety of implants, including joints, spine, bone traumas, etc. [12,13,35]. The Young's modulus of titanium and titanium alloy is around $110 \mathrm{GPa}$, far exceeding the natural bone with a modulus of 15-30 GPa [36]. According to Wolff's functional recovery theorem, the modulus of the materials affects the response of the bone tissue to the fixed implant [37]. Studies have shown that low Young's modulus titanium alloy implants have smaller stress shielding [38]. In the case of using a bone plate fixed by screws [39], bone atrophy and refracturing due to uneven stress transmission between the bone plate and the bone cause the bone screw to loosen, which seriously hinders the therapeutic effect of the implant. Therefore, low modulus titanium alloys ( $\beta$-titanium alloys, etc.) are considered to have better biomechanical advantages [40].

The Ni-Ti alloy has pseudoelasticity and shape memory effect, which makes it similar to the recoverability of the bone [41]. Therefore, $\mathrm{Ni}$-Ti alloy is also a biocompatible metal material [42]. Considering that $\mathrm{Nb}$ has excellent corrosion resistance, chemical inertness, and is harmless to the human body [43], it can be combined with biocompatible Ti to form biocompatible Ti-Nb alloys, for example, Ti-6Al-7Nb [44]. However, $\mathrm{Al}, \mathrm{V}$, and $\mathrm{Ni}$ are toxic ions and should not be released inside the human body. Thus, alloys such as Ti-27.5Nb [45], Ti-42Nb [46], etc., which are biomedical materials with excellent properties, are used as alternatives to Ti-6Al-4V and $\mathrm{Ni}-\mathrm{Ti}$ alloys.

The medical cobalt-chromium alloy has good corrosion resistance and excellent mechanical properties. One of its main medical applications is the $\mathrm{Co}-\mathrm{Cr}-\mathrm{Mo}$ alloy, which has been applied to the manufacture of dental and artificial joints [47]. It can be manufactured by PBF technology. Hazlehurst et al. used SLM to fabricate porous $\mathrm{Co}-\mathrm{Cr}-\mathrm{Mo}$ alloy, and studied its quasi-static compression properties. They found that the porous cobalt-chromium alloy satisfies the mechanical performance requirements of implants [48].

Biocompatible medical stainless steel has been used in medical implants for a long time, mainly 316L stainless steel (316L SS). Because of its fine mechanical properties and low cost, it is the first material used for the repair and replacement of hard tissues in the human body, especially in the acetabular cup, which occupies half of the artificial hip joint product [49]. Jandin et al. successfully prepared porous stainless steel materials using SLM for the first time [50]. Then, Čapek et al. found that porous stainless steel using SLM has superior composite performance compared to solid stainless steel specimens obtained by casting and hot forging [51]. Furthermore, Wehmoller et al. successfully prepared a series of 316L SS implants using SLM technology [52]. They all confirmed that SLM is a suitable technology for forming high porosity stainless steel implants.

\section{(2) Expensive metals}

In addition to common metals, tantalum has the characteristics of hardness, toughness, chemical resistance, and good compatibility with human bones [53], and is also a biocompatible material. The most common application to implants is porous tantalum (also known as Trabecular Metal). The trabecular metal has an open-cell structure with excellent biocompatibility, high porosity, and a low modulus of elasticity, which is similar to the trabecular bone. Therefore, it has been clinically applied 
to the orthopedic implant [54]. Figure 3a shows some examples of porous tantalum implant. However, the molding quality of the porous tantalum implant is greatly affected by the irregular shape of the powder. To solve this problem, Sungail et al. used the additive manufacturing technology to prepare porous tantalum of higher surface quality by spheroidizing the tantalum powder [55]. Wauthle et al. used SLM to manufacture internal interconnected porous tantalum implants [56], whose mechanical properties were matched with human bones. The results of in vivo implantation experiments showed that the contact interface between the implant and bone tissue was well combined, which implied porous tantalum is favorable for bone replacement.

Additionally, some precious metals have a beautiful color, very stable chemical properties, and excellent biocompatibility. They are widely used in dental implants, such as gold, platinum group metals (platinum, palladium), and silver and their alloys [30]. In general, precious metal dental materials often contain a variety of metals, taking into account the cost of the material and the performance requirements of the implant. As the earliest metal material used in dentistry, gold is commonly used in the production of dental filling materials, crowns, and dentures. Although it is expensive, it has admirable performance, including beautiful color, inert chemical property, corrosion resistance, and excellent biocompatibility. It is commonly used in alloy matrix materials [57], forming such as $\mathrm{Au}-\mathrm{Pt}-\mathrm{Pd}, \mathrm{Au}-\mathrm{Pd}-\mathrm{Ag}$, $\mathrm{Au}-\mathrm{Pd}$, and $\mathrm{Au}-\mathrm{Ag}-\mathrm{Cu}$ alloys [58].

Due to the high price of gold, gold content is reduced to reduce the cost, but in order to ensure the corrosion resistance of the implant, the platinum group element palladium is added to increase the palladium content, and high-palladium alloys such as $\mathrm{Pd}-\mathrm{Cu}-\mathrm{Ga}, \mathrm{Pd}-\mathrm{Ga}, \mathrm{Pd}-\mathrm{Ag}$ alloy, etc. are formed $[59,60]$. Because of its relatively low price, the expansion coefficient is matched with ceramics. The resulting ceramic sintered alloy has better performance and is commonly used as a bridge. However, clinical allergic cases of palladium alloys in recent years indicate that palladium has potentially toxic effects on humans [61,62], and the specific reasons for palladium allergy need to further study. Moreover, silver and its alloys are widely used as dentures. Pure silver is soft and not wear-resistant; its corrosion resistance is not as good as that of the gold alloy. It is easy to change color and lose color in the oral cavity [63], but it has a low price and good processing and casting performance. Thus, the silver alloy like $\mathrm{Ag}-\mathrm{Pd}$ and $\mathrm{Ag}-\mathrm{Cu}-\mathrm{Pd}-\mathrm{Au}$ formed by compounding with other precious metals can be used as crowns, bridges, and inlays, etc. [64].

Degradable metals

The above biomedical metals are all non-degradable. In recent years, degradable metals are also used to repair bone defects, particularly in the bone scaffold, which can completely regenerate the defective bone. Among the degradable metals, magnesium metal has attracted much attention, because magnesium ion is the fourth largest cation in the human body, and it mainly exists in bone tissue and participates in its metabolism $[65,66]$, which is beneficial to the growth of bone tissue. Researchers have applied magnesium metal in implants. For example, Chung et al. [67] successfully manufactured a pure magnesium sample, which has a lower modulus of elasticity and strength, using SLM for the first time. The sample's mechanical properties are very close to natural bones. Zhang et al. [31] fabricated porous magnesium with interconnected pores. Moreover, they found that porous magnesium of $33-54 \%$ porosity is comparable to the cortical bone in the modulus, indicating that porous magnesium has the potential to be the bone scaffold. However, the active chemical nature of magnesium will cause big problems in medical applications because of hydrogen release during the corrosion process. This issue can be improved by alloying magnesium with other elements to change its physical and chemical properties [68-71].

Another shortcoming of magnesium is its rapid degradation. Unlike magnesium, as a degradable biocompatible metal material, iron has a slower degradation rate [72]. Using the porous structure with a high surface area can effectively increase the degradation rate of the iron-based alloy [73]. Meanwhile, iron-alloys have better strength and toughness than magnesium alloys and can be applied to cardiovascular stents and bone stents [74,75]. 
Compared to magnesium and iron, zinc has a moderate degradation rate [76]. The latter is also an essential element in the body so that it can be used to orthopedic implants [77], as shown in Figure 3b. In contrast, the processing of zinc by SLM is a challenge because of the low melting point and boiling point, causing the prepared sample is low-density and unstable [32]. By optimizing the powder and processing technology, the quality of the prototype can be effectively improved, thereby realizing the preparation of zinc implants with excellent properties [78]. However, pure zinc is difficult to satisfy the clinical mechanical requirements of bearing bone. Compounding with other elements to form the zinc-based alloys can guarantee the mechanical properties and degradability [79-81].
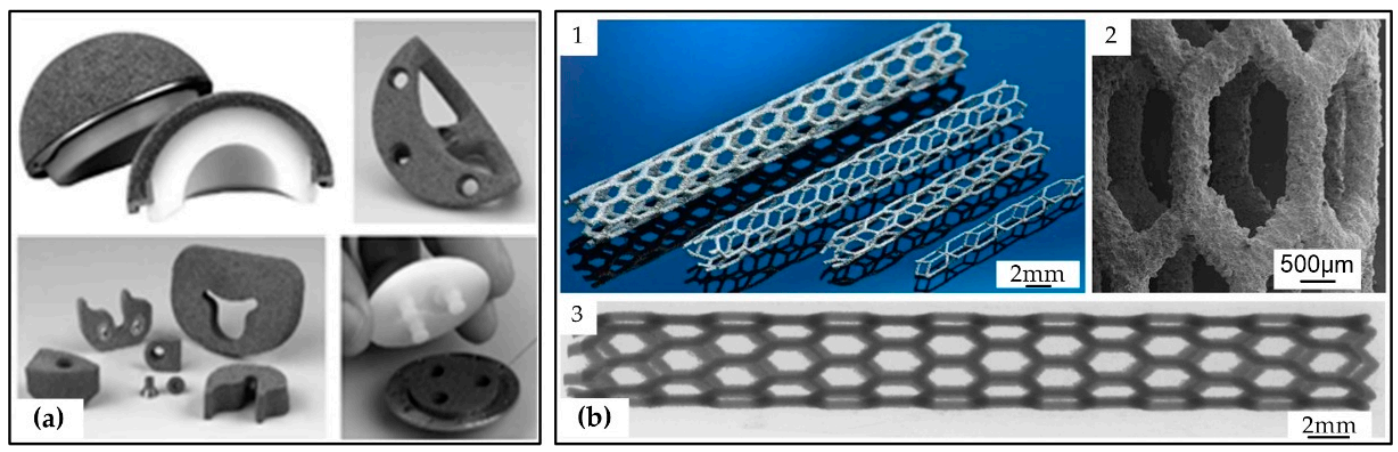

Figure 3. Some metallic orthopedic implants: (a) porous tantalum implant, top row: acetabulum implant. Bottom row: total knee arthroplasty (TKA) implants, and patella implant, reproduced from [54], with copyright permission from Elsevier, 2006; (b) zinc metal heart stent, reproduced from [77], with copyright permission from Elsevier, 2018; 1 . The samples, 2. The scanning electron microscope (SEM) picture, 3. The X-ray graph.

With the development of materials science, more composite metal materials have emerged, which means we have a wide range of available metal implant materials. We can choose biomedical metal materials according to our goals and their properties. The properties of different biomedical metals are illustrated in Table 1. For traditional bone implant manufacturing processes, the metal material selection depends on both performance and cost. Additive manufacturing techniques, however, are no longer impacted by the choice of materials. They tailor materials according to the specific needs of the customized implant. There is the clinical application of common metal implants as shown in Figure 4. Selecting the appropriate metal material according to the bone repair area can integrate the mechanical properties and biological properties of the implant, which is the trend of implant materials.

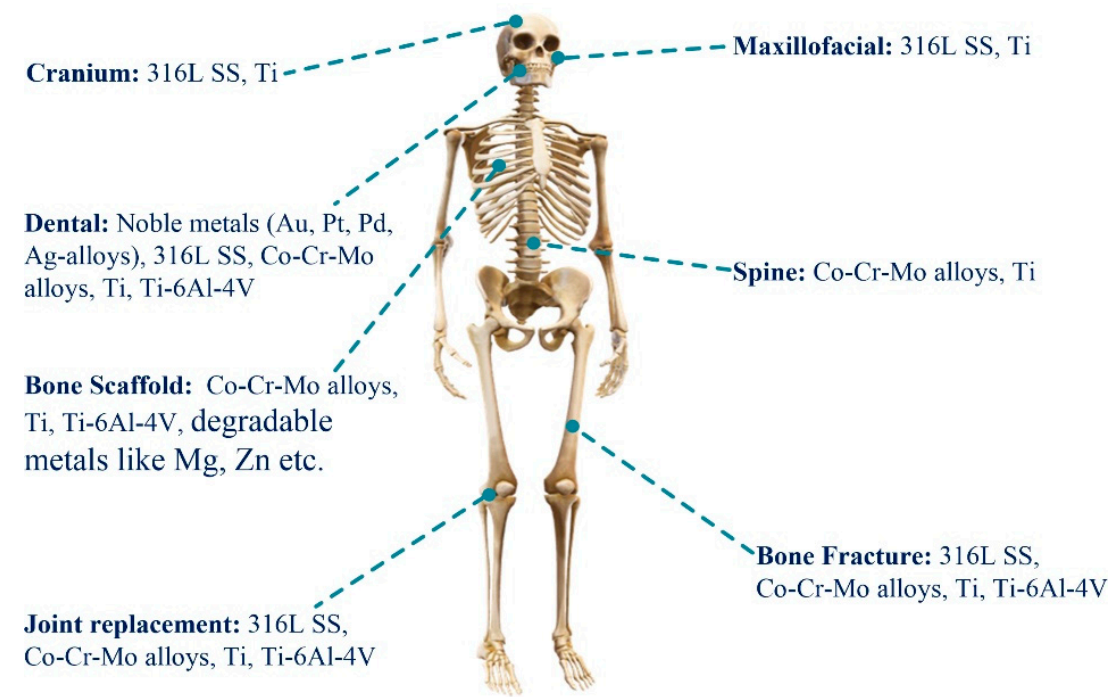

Figure 4. The clinical application of common metal implants. 
Table 1. The properties of different biomedical metals.

\begin{tabular}{|c|c|c|c|c|c|c|}
\hline \multirow[b]{2}{*}{ Materials } & \multicolumn{3}{|c|}{ Mechanical Property } & \multirow{2}{*}{ Physicochemical Property } & \multirow{2}{*}{$\begin{array}{c}\text { Material } \\
\text { Degradability }\end{array}$} & \multirow{2}{*}{ Main Application } \\
\hline & $\begin{array}{l}\text { Young Modulus } \\
\text { (GPa) }\end{array}$ & Yield Strength (MPa) & $\begin{array}{l}\text { Tensile Strength } \\
\text { (MPa) }\end{array}$ & & & \\
\hline Pure Ti [34] & 105 & 695 & 785 & $\begin{array}{l}\text { Superior biocompatibility, good } \\
\text { corrosion resistance, and relatively } \\
\text { inert }\end{array}$ & Non-degradable & $\begin{array}{ll}\text { - } & \text { Joint replacement } \\
\text { - } & \text { Bone defect repair } \\
\text { - } & \text { Spinal fusion } \\
\text { - } & \text { Bone scaffold }\end{array}$ \\
\hline Ti-6Al-4V alloy [34] & 110 & $850-900$ & $960-970$ & $\begin{array}{c}\text { Good biocompatibility, good } \\
\text { corrosion resistance, and relatively } \\
\text { inert }\end{array}$ & Non-degradable & $\begin{array}{ll}\text { - } & \text { Joint replacement } \\
\text { - } & \text { Bone defect repair } \\
\text { - } & \text { Bone scaffold }\end{array}$ \\
\hline $\begin{array}{c}\text { Co-Cr-Mo alloy } \\
{[47,82]}\end{array}$ & 230 & $200-823$ & $430-1028$ & $\begin{array}{l}\text { Little biological toxicity, excellent } \\
\text { corrosion and wear resistance }\end{array}$ & Non-degradable & $\begin{array}{l}\text { - Joint replacement } \\
\text { - } \quad \text { Dental implant } \\
\text { - Bone scaffold }\end{array}$ \\
\hline $\begin{array}{c}\text { 316L stainless steel } \\
{[47,49]}\end{array}$ & 193 & 290 & 579 & $\begin{array}{l}\text { Acceptable biocompatibility and } \\
\text { good corrosion resistance, bio-inert } \\
\text { materials }\end{array}$ & Non-degradable & $\begin{array}{ll}\text { - } & \text { Joint replacement } \\
\text { - } & \text { Bone defect repair } \\
\text { - } & \text { Dental implant }\end{array}$ \\
\hline $\begin{array}{c}\text { Tantalum metal } \\
{[54,56]}\end{array}$ & 186 & $138-345$ & $207-517$ & $\begin{array}{l}\text { Non-toxic, excellent } \\
\text { biocompatibility, relatively inert, } \\
\text { stable characteristic }\end{array}$ & Non-degradable & - Joint replacement \\
\hline Gold $[30,58]$ & 80 & 25 & 130 & $\begin{array}{l}\text { Excellent biocompatibility, } \\
\text { superior corrosion resistance, and } \\
\text { completely unreactive }\end{array}$ & Non-degradable & - Dental implant \\
\hline $\begin{array}{c}\text { Platinum metal } \\
{[30,83]}\end{array}$ & 147 & 150 & 240 & $\begin{array}{l}\text { Excellent biocompatibility, } \\
\text { superior corrosion resistance, and } \\
\text { strong chemic inertia }\end{array}$ & Non-degradable & $\begin{array}{ll}\text { - } & \text { Dental implant } \\
\text { - } & \text { Stent }\end{array}$ \\
\hline $\begin{array}{l}\text { Palladium metal } \\
{[30,84]}\end{array}$ & 112 & 50 & 190 & $\begin{array}{l}\text { Excellent biocompatibility, } \\
\text { superior corrosion resistance, and } \\
\text { strong chemic inertia }\end{array}$ & Non-degradable & - Dental implant \\
\hline Silver $[30,63]$ & 76 & 28 & 150 & $\begin{array}{l}\text { Good biocompatibility, good } \\
\text { corrosion resistance, and relative } \\
\text { chemic inertia }\end{array}$ & Non-degradable & - Dental implant \\
\hline
\end{tabular}


Table 1. Cont

\begin{tabular}{|c|c|c|c|c|c|c|}
\hline \multirow[b]{2}{*}{ Materials } & \multicolumn{3}{|c|}{ Mechanical Property } & \multirow[b]{2}{*}{ Physicochemical Property } & \multirow{2}{*}{$\begin{array}{c}\text { Material } \\
\text { Degradability }\end{array}$} & \multirow[b]{2}{*}{ Main Application } \\
\hline & $\begin{array}{l}\text { Young Modulus } \\
\text { (GPa) }\end{array}$ & Yield Strength (MPa) & $\begin{array}{c}\text { Tensile Strength } \\
\text { (MPa) }\end{array}$ & & & \\
\hline $\begin{array}{c}\text { Magnesium metal } \\
{[71,85]}\end{array}$ & 44.2 & 162 & 250 & $\begin{array}{l}\text { Outstanding biocompatibility, } \\
\text { promoting bone tissue } \\
\text { regeneration. Active nature, } \\
\text { corrosive in a weak alkaline } \\
\text { environment, and the corrosion } \\
\text { product is non-toxic }\end{array}$ & $\begin{array}{l}\text { Degradable, fast } \\
\text { degradation rate }\end{array}$ & - $\quad$ Bone scaffold \\
\hline Iron metal [73] & 200 & 50 & 540 & $\begin{array}{l}\text { Appropriate biocompatibility, less } \\
\text { active properties, and slower } \\
\text { corrosion dissolution }\end{array}$ & $\begin{array}{l}\text { Degradable, slow } \\
\text { degradation rate }\end{array}$ & - $\quad$ Bone scaffold \\
\hline Zinc metal $[77,86]$ & 96.5 & 30 & 37 & $\begin{array}{c}\text { Good biocompatibility, active } \\
\text { nature, and corrosive dissolved } \\
\text { substances in the body are not } \\
\text { poisonous }\end{array}$ & $\begin{array}{l}\text { Degradable, moderate } \\
\text { degradation rate }\end{array}$ & - Bone scaffold \\
\hline Cortical bone [36] & $15-30$ & $30-70$ & $70-150$ & & null & \\
\hline
\end{tabular}




\section{Design Customized Implants to Match the Bone}

A reasonable customized orthopedic implant should match the bone defect and stimulate bone tissue regeneration. Generally, the design process of implants is shown in Figure 5 below. The requirements of the implant and the computed tomography (CT) imaging data, which contains the outer contour of the defect area [87], should be acquired beforehand. Because the implant structure directly determines the final performance of the implant, it was first designed by computer-aided design (CAD). When getting the CAD models, finite element simulation is carried out to check the structure. The simulation can make some adjustment until the structure satisfies the need. Then, the implant is manufactured using additive manufacturing. After that, the surface of the implant is modified to improve the bio-function of the implant. In the end, the performance of the implant was verified by a series of experiments and fed back into the CAD design. The entire implant design process contains a lot of content, among which the topology is related to the mechanical properties of the implant, and the surface treatment affects the biological properties of the implant. Therefore, numerous researchers focus on these two points, they mainly explored the adaptability of different porous structures and biofunctionality of surfaces with different treatments.

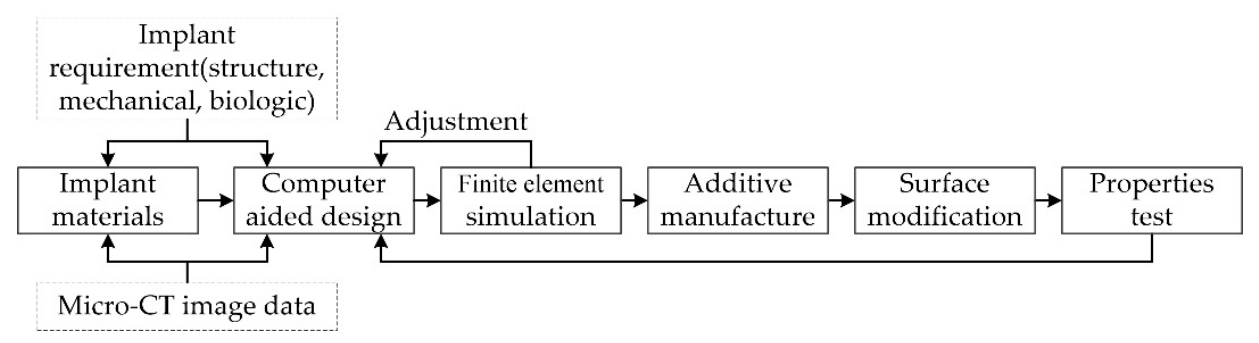

Figure 5. Flow chart of designing a customized implant.

\subsection{Topology Structure Design}

As can be known from Figure 6, the internal structure of the bone is loose and porous. Therefore, a reasonable implant structure should be porous to promote the transport of nutrients, oxygen, etc. Moreover, the porous structure has a large specific surface area, which facilitates cell adhesion and promotes vascularization [88]. For the high elastic modulus of the metal, the porous structure also reduces its modulus to fit the modulus of the bone. In other words, porous implants are suitable for a bone defect in morphological and physicochemical properties. As the key parameters of the porous structure, pore size, pore geometry, and porosity directly affect the regeneration of bone tissue [89], which are the main research topics of current implant structure.

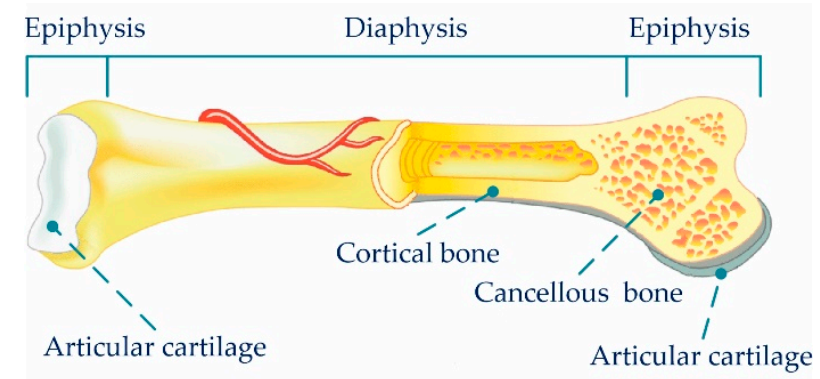

Figure 6. The anatomy of a long human bone.

On the one hand, the implant should have reasonable pore size. It is generally recommended that the pore size is greater than $300 \mu \mathrm{m}$ [90]. However, a large pore size often leads to cell adhesion difficulty, which goes against bone tissue regeneration and reduces the mechanical properties of the implant. Studies have shown that the pore size should range from $300 \mu \mathrm{m}$ to $800 \mu \mathrm{m}$ to satisfy the biofunctional requirements of the implants [8]. 
Apart from the pore size, the mechanical loading of the bone deeply affects bone regeneration [91]. In practice, the mechanical load of the defective bone is transferred to the bone substitute and the fixed plate, and the amount of the share depends on the stiffness of the implant [23]. Adjusting the porosity and microstructure can change the elastic modulus of the implant, which also affects bone regeneration [92,93]. The common method of changing the porosity is to adjust the thickness of the rod and the diameter of the rod. In the porous structure, the thick rod leads to a decrease in porosity, and the relative density of the structure becomes larger. According to the Gibson-Ashby model [94], the modulus is larger under the same topology, which means higher strength and better carrying capacity. Moreover, the cross-sectional shape of the rod also affects mechanical properties. Studies have shown that under the same load, the bone scaffold of the square section rod has a higher bearing capacity than the circular section [95].

Moreover, during the design process, it is critical to consider the limitations of the processing system, which often has the minimum processing strut diameter [96], and the error of the additive manufacturing sample with smaller rod diameter is larger, and the samples with larger rod diameter have less error [97]. Thus, selecting a rod diameter suitable for AM processing can further ensure the effectiveness of the design. Generally speaking, porosity correlates with the pore size and the strut diameter, which can be varied by adjusting either parameter. In contrast, different topology configurations of the structure are more attractive for the researches. If the internal topology structure is rationally designed, the implant's ability to promote bone regeneration can be enhanced.

\subsubsection{Lattice Structure Design}

The lattice structure is arranged periodically by unit cells and has a high regularity. Furthermore, the homogenization theory can extend the analysis of unit cells to the performance analysis of the overall structure. That will greatly improve the accuracy of the structure performance prediction. Because of the easy manufacturability and the open-pore structure of the lattice structure, it can realize the porous characteristics of the implant. As a result, many lattice structures have already been applied to the design of implant structures, and even a design scheme based on the lattice library has been formed $[98,99]$. Common lattice structures that are successfully applied in implants include polyhedral models based on CAD, models based on implicit surfaces, and models based on topological optimization, etc., as shown in Figure 7.

For lattice structures that are applied to orthopedic implants, many researchers study the mechanical properties of these different configurations of lattice structures, and the influencing factors of their mechanical properties on implants are gradually explored. It is recognized that the most important mechanical properties are the quasi-static mechanical response and fatigue characteristics. Herein, the review of the lattice structure is classified based on the above classification rules. The corresponding laws are summarized, thereby guiding the design of new lattice structure implants.

\section{(1) Lattice structure based on the polyhedral structure}

The polyhedral lattice structure is based on the geometric polyhedron configuration, which has many types. Based on the traditional beam element model for theoretical derivation, the relationship between its structural mechanical properties and dimensional parameters can be established [100-102]. That makes the prediction of the mechanical properties of the polyhedral structure more accurate, and the design of the lattice structure is less difficult. Therefore, the polyhedral lattice structure becomes the most widely used structure in the implant. Rodríguez-Montaño et al. [95] designed four kinds of lattice structures, namely the truncated cuboctahedron, the truncated cube, the rhombic dodecahedron, and the diamond. The cross section of the rods in these lattices structures is all circular. Additionally, the mechanical properties of the different structures are discussed, finding that the hexahedron structure is most favorable the formation of bone, which offers a better choice of the implant structure.

Furthermore, Ahmadi et al. [7] studied the differences in mechanical properties caused by the shape configuration of beam elements on a larger scale, and established six lattice structures of the 
cubic, the diamond, the truncated cube, the truncated cuboctahedron, the rhombic dodecahedron, and the rhombicuboctahedron, the rods of which are all square. And the possibility of these lattice structures as implant structures was fully verified via extensive experimental data. Moreover, Wang et al. [103] successfully applied the tetrahedral lattice structure to the implant. Other researchers have also studied the polyhedral lattice structures [6,104,105], which further broaden the choice of implant structure.

Among them, the diamond structure is similar to the cancellous bone in that the close angle between inter-rod angle and the inter-trabecular angle [106]; thus, it has inherent advantages of similar microstructures. Jett et al. applied the diamond lattice structure to the filling of the femoral stem [107], which realized better mechanical properties that match with the bone. Because the transition of the diamond structure joint influences the permeability and mechanical properties of the structure, the surface stress concentration can be reduced by smoothing the surface, thereby generating the optimized diamond lattice structure [108]. Experiments show that the structure has better mechanical properties and can meet the mechanical performance requirements of the implant.

\section{(2) Lattice structure based on the implicit function surface}

This kind of lattice structure is usually designed by the triply periodic minimal surfaces (TPMS), which have many advantages such as unique topological shape, smooth surface, high specific surface area, low stiffness and high strength of the structure, high permeability, and is similar to the microstructure of the trabecular bone. Thus, it is introduced as an attractive candidate for the topology configuration of orthopedic implants [109-111]. Yoo et al. [112] successfully filled minimal surface structures into clinical implants, but it was limited to structural design, without further exploration of its biological functionality. Bobbert et al. [8] used the K3D surf and CAD modeling software to establish four minimum surface lattice structures; namely, the Schwartz primitive, the I-WP, the Schoen's gyroid, and the Schwartz diamond. The mechanical properties and permeability of the SLM manufactured corresponding samples were verified, and the results indicate that the minimal surface structure has a good application prospect in the orthopedic implant structure.

Moreover, Al-Ketan et al. [113] used Boolean operations to transform the minimal surface into two types of structures, the solid structure and the sheet structure, which is expounded in detail in the literature [114]. These works extend the minimal surface structure from modeling. The $64 \%$ porosity Ti-6Al-4V primitive lattice structures manufactured by SLM has similar mechanical properties to the cortical bone [110]. Other related researches have focused on exploring the mechanical response of the minimal structure with different porosity, especially for gyroid surfaces $[110,111,115]$.

\section{(3) Lattice structure based on topology optimization design}

Topology optimization has been used as a common method for designing a structure and has achieved abundant achievements in other fields [116-118]. This method can also obtain the microstructure that matches the implant structure well. For example, the bidirectional evolutionary structural optimization (BESO) method, proposed by Xie [119], is a very effective continuous structure optimization method that can control the total volume by reducing or increasing the material in the optimization process via iteration. Using this method, based on volume constraints and modulus requirements, they obtained better bone morphology bionic microstructure [120]. Moreover, another optimization method, multi-phase topology optimization (MPTO), proposed by Burblies to achieve the minimum structural strain energy, the optimized structure based on which also has favorable structural characteristics [121]. These topologically optimized structures all have smooth surfaces and high strength, and they are very similar to natural bone structure, which has great potential to realize the implant structures. 

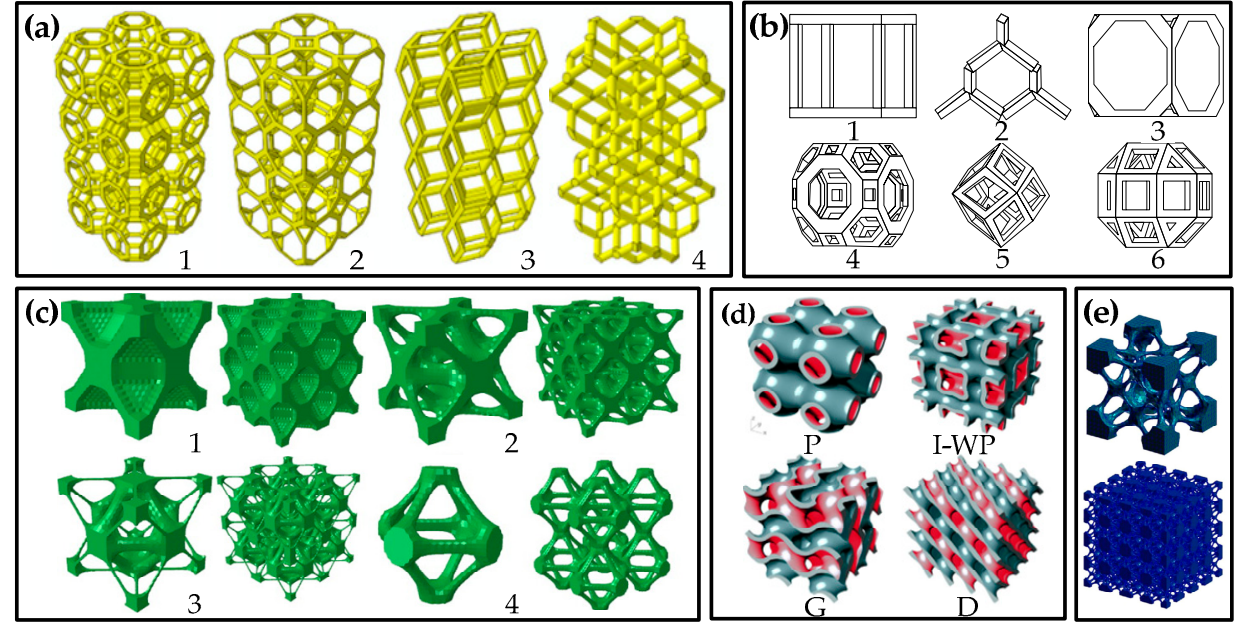

Figure 7. Common lattice structure design: (a) Polyhedral model (circular), reproduced from [95], with copyright permission from Elsevier, 2018, from left to right: Truncated cuboctahedron, Truncated cube, Rhombic dodecahedron, and Diamond; (b) polyhedral model (square), reproduced from [7], with copyright permission from authors, 2015, according to the serial number: Cubic, Diamond, Truncated cube, Truncated cuboctahedron, Rhombic dodecahedron, and Rhombicuboctahedron; (c) topology configuration based on BESO, reproduced from [120], with copyright permission from Elsevier, 2011, the topological unit cell and the overall structure obtained according to the volume fraction is $40 \%, 30 \%$, $20 \%, 10 \%$ in order; (d) common four triply periodic minimal surfaces (TPMS) structures, reproduced from [8], with copyright permission from Elsevier, 2017, Prime, I-WP, Gyroid, and Diamond in order; (e). Three-dimensional porous structure based on the multi-phase topology optimization (MPTO) method reproduced from [121], with copyright permission from AIP Publishing, 2008, unit cell and overall structure.

\subsubsection{Gradient Structure Design}

The internal structure of human bones is complex, and the bone structure varies in different regions. Although the periodic lattice material can be adopted as the implant structure due to its porous characteristics, the structural topography only has one single structure, which is quite different from the actual topological morphology of the bone. Using these lattice structures as long-term implants will probably cause inflammation, rejection, and other reactions of surrounding tissues. Recently, functionally graded materials (FGM) gradually become the focus of the implant structure research, which can provide a new approach for the implant structure design, as it has excellent performance, adaptive variable porosity, and many other advantages. This way, an implant with a porous gradient structure to replicate the natural characteristics of the bone can be designed [122], which will greatly enhance the compatibility of the implant with bone tissue.

Currently, structural gradient design strategies mainly include:

(1) Unit cell changes in rod diameter [123]. For a polyhedral structure, it can be viewed as a myriad of rods connecting each other. Thus, altering the rod diameter can achieve a density gradient of the overall structure. When modeling, the structure is sliced into multiple layers. The rod diameters of each layer vary, thereby changing the overall density of the lattice structure.

(2) Unit cell changes in size [124]. The implant is composed of a plurality of unit cells. By adjusting the cell size in different regions, the gradient of the implant structure can be realized while the rod diameter and the pore diameter are ensured.

(3) Unit cell changes in type [125]. Due to the change of bone structure, the unit cells in different regions will theoretically have certain variability. The implants containing multiple isomers can realize the gradient of the structure via different unit cells. 
(4) Material composition changes [126]. The change of the material composition can also achieve the structural gradient. The most common method is to change the content of the other materials within one matrix material to realize the functional gradient of the structure.

Figure 8 shows some examples of the different types of gradient structures.
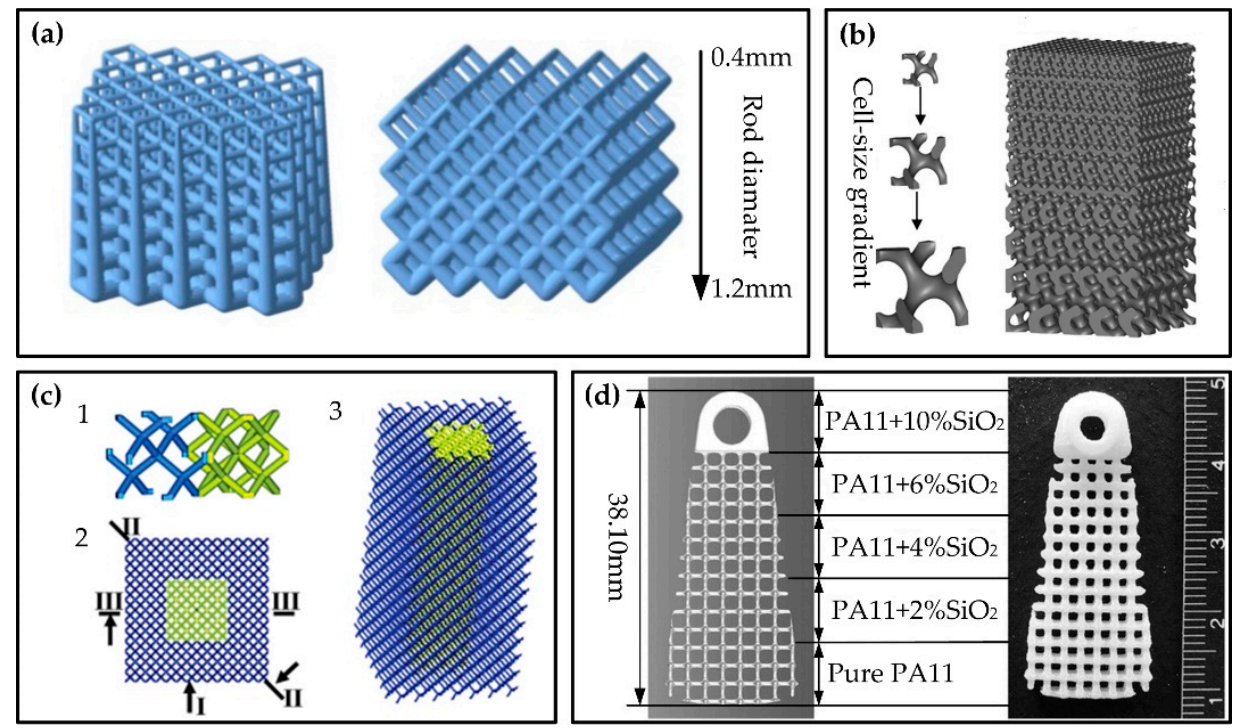

Figure 8. Common gradient structure design: (a) gradient structure formed by rod diameter variation, reproduced from [123], with copyright permission from Elsevier, 2017; (b) gradient structure formed by unit cell size change, reproduced from [124], with copyright permission from Elsevier, 2018; (c) gradient structure formed by three different unit cell structures: 1 . two types of composition unit cell; 2 . top view of the overall structure; 3 overall three-dimensional structure schematic, reproduced from [125], with copyright permission from John Wiley and Sons, 2015. (d) The gradient structure of the rotator cuff formed by different material components, reproduced from [126], with copyright permission from Elsevier, 2008.

A series of gradient implant structures can be obtained by applying the common gradient lattice structure, such as the polyhedral gradient structures and the gradient minimal surface structures. The polyhedral structure has a simple topology, and its gradient strategy is easier than the surface structure. Therefore, a relatively large number of gradient structures are formed, including the gradient cubic lattice, the gradient honeycomb structure, the gradient body-centered cubic (BCC) lattice, and the gradient diamond lattice. For example, Choy et al. [123] proposed two cubic and honeycomb gradient lattice structures by using the rod diameter variation strategy. Onal et al. [9] designed two BCC structures with density gradient changes by varying the rod diameter; the structures are beneficial to cell diffusion and proliferation and can maximize the mechanical and biological properties of the implant. Moreover, for the diamond lattice structure, Dumas et al. [127] successfully applied its gradient structure to a partially porous femoral stem. Experiments showed the graded diamond structures are suitable for biomedical application. However, this work only considers the mechanical properties of the implant. Furthermore, Zhang et al. [128,129] explored a more complex diamond lattice gradient strategy, achieving a gradient structure implant with rational permeability and mechanical properties.

To design the gradient triply periodic minimal surfaces structure, Maskery et al. [130] used two strategies, changing the rod diameter and hybridizing different unit cell types, which create a gradient of minimal surface structure. Similarly, Vijayavenkataraman et al. [131] applied gradient strategies (changing rod diameter, cell size, and unit cell type) to three TPMSs (P, G, and D surface) to achieve the design of the biomimetic implants, which are satisfied with multiple requirements like porosity, modulus and pore size etc. In addition, other researchers have established gradient minimal surface structures for implants [124,132-134]. However, the gradient direction of all the above implants is 
consistent with the loading direction, which is the longitudinal direction. For the real bone structure, it also has a large change in the radial direction. Therefore, from the perspective of bone bionics, designing the radial gradient structure is another approach. Afshar et al. [135] studied the compression characteristics of several radial gradient minimal surface structures (I-WP, P, and D) using experiments and finite element simulations. Furthermore, Feng et al. [136] used solid T-splines to achieve a more complex gradient design, which effectively confirms the advantages of gradient minimal surface structure in the implants.

The above strategy will make modeling very cumbersome, especially when implementing large-scale structural gradients. Thus, Sudarmadji et al. [137] designed a new polyhedral lattice via combining different polyhedral to realize the stiffness combinations, which makes the structure match with the bone. This design method does not require the operator skilled in using CAD modeling software, and it can reduce the design difficulty and improve design efficiency. Moreover, the poor interface between the different unit cell configurations is still to be solved. Based on the structural gradient design via changes in material compositions, Torres et al. [138] used $\mathrm{NaCl}$ as a support structure to mix with the titanium powder. When the $\mathrm{NaCl}$ was dissolved in water, the porous titanium structure can be formed. The change in the structural porosity of this lattice structure can be easily modified by adjusting the $\mathrm{NaCl}$ content, which provides a new approach for the implant gradient structure design. All implant structure design methods are shown in Table 2.

Table 2. Summary of implant structure design.

\begin{tabular}{|c|c|c|c|c|}
\hline \multicolumn{2}{|c|}{ Structure Types } & \multirow{2}{*}{\begin{tabular}{l}
\multicolumn{1}{c}{ Structure Characteristics } \\
Based on polyhedral geometry, \\
CAD modeling, simple \\
structure, and predictable \\
mechanical properties, most \\
widely used.
\end{tabular}} & \multirow{2}{*}{$\begin{array}{l}\text { Materials/Methods } \\
\text { Ti-6Al-7Nb/SLM [44] } \\
\text { Ti-6Al-4V/SLM } \\
{[103,104,107,108] \text { 316L }} \\
\text { SS/SLM [100] }\end{array}$} & \multirow{2}{*}{$\begin{array}{l}\text { Process Attributes } \\
\text { High resolution; good } \\
\text { implant porosity; high } \\
\text { strength, low ductility; } \\
\text { good osteointegration. }\end{array}$} \\
\hline Lattice structure & Polyhedron & & & \\
\hline \multirow{5}{*}{ Gradient structure } & Minimal surface & $\begin{array}{l}\text { Based on implicit function, } \\
\text { complex structure, high } \\
\text { specific surface area, and high } \\
\text { permeability, similar to } \\
\text { trabecular bone. }\end{array}$ & $\begin{array}{l}\text { Ti-6Al-4V/SLM } \\
{[109,115]} \\
\text { Ti-6Al-4V/EBM [110] } \\
\text { Pure Ti/SLM [111] } \\
\text { Ti-6Al-4V/SLS [114] }\end{array}$ & $\begin{array}{l}\text { Fine molding quality; high } \\
\text { porosity; good } \\
\text { biocompatibility; excellent } \\
\text { mechanical properties. }\end{array}$ \\
\hline & $\begin{array}{l}\text { Topology } \\
\text { optimization } \\
\text { design }\end{array}$ & $\begin{array}{l}\text { Based on boundary conditions } \\
\text { and optimization algorithms, } \\
\text { smooth surface, and high } \\
\text { strength, similar to natural } \\
\text { bone structure. }\end{array}$ & $\begin{array}{l}\text { Ti-6Al-4V/SLM [116] } \\
\text { Pure Ti/SLM [121] }\end{array}$ & $\begin{array}{l}\text { Fine molding quality; } \\
\text { lightweight design; stable } \\
\text { structure. }\end{array}$ \\
\hline & Vary in cell size & $\begin{array}{l}\text { Varied in cell size; } \\
\text { non-stationary transitions } \\
\text { between different layers. }\end{array}$ & $\begin{array}{l}\text { Ti-6Al-4V/EBM [123] } \\
\text { Ti-6Al-4V/SLM [124] }\end{array}$ & $\begin{array}{l}\text { Fine molding quality; } \\
\text { appropriate modulus; high } \\
\text { energy absorption. }\end{array}$ \\
\hline & $\begin{array}{c}\text { Vary in cell types } \\
{[130,131,137]}\end{array}$ & $\begin{array}{l}\text { Varied in unit cell type, } \\
\text { different areas have different } \\
\text { topologies; non-stationary } \\
\text { transitions between different } \\
\text { layers. }\end{array}$ & Ti-6Al-4V/EBM [125] & $\begin{array}{l}\text { High energy absorption; } \\
\text { appropriate modulus; } \\
\text { biomimetic bone structure. }\end{array}$ \\
\hline & $\begin{array}{l}\text { Vary in materials } \\
\text { components } \\
{[126,138]}\end{array}$ & $\begin{array}{l}\text { Varied material components, } \\
\text { different areas only show } \\
\text { material changes, relatively } \\
\text { stable structure, and } \\
\text { significant compatibility } \\
\text { between different layers. }\end{array}$ & PA 11/SLS [126] & $\begin{array}{l}\text { Biomimetic graded } \\
\text { porosity; appropriate } \\
\text { modulus; stable } \\
\text { microstructure. }\end{array}$ \\
\hline
\end{tabular}

\subsection{Surface Modification}

The surface quality of the implant directly affects its biological performance, such as the biocompatibility and the osteogenesis of the implant [139]. Thus, it is necessary to modify the surface to enhance the biological function of the implant. In recent years, many surface modification methods are used to accelerate and enhance bone regeneration further. These mainly include: 
(1) Chemically roughening the surface

Chemical modification of the implant surface to obtain a rough surface can effectively improve the biological function of the implant. It expands the contact area with the surrounding bone tissue and facilitates the attachment of bone cells, which is conducive to the formation of the mechanical interlocking fixation.

Heinl et al. [140] used $\mathrm{HCl}$ and $\mathrm{NaOH}$ to modify on the surface of porous titanium alloy (Ti-6Al-4V) implants, which induced the formation of the surface apatite and promoted the osteogenesis of the implant. This implant can better fit the bone tissue, thereby improving the stability of the implant for long-term use. Korobkova et al. [141] performed an alkali-heat treatment on the surface of a superelastic titanium alloy (Ti-22Nb-6Zr) to enable the surface to form a hydroxyapatite structure of a bone-like structure. More modifications are discussed in the literature [142], i.e., acid-alkali (AcAl), alkali-acid-heat $(\mathrm{AlAcH})$, and anodizing-heat $(\mathrm{AnH})$. Through the apatite-forming ability test, the cell experiments, and the animal experiments, the biological functions such as osteogenic ability, cell proliferation, and differentiation characteristics were systematically evaluated. Structural biological functions obtained by different surface modifications were found different. Bio-characteristics will not reach as expected when osteogenic capacity is enhanced, indicating that the ability to individually verify bone formation is not very accurate for the overall biofunctional assessment of the implant. Other chemical modifications such as hydrogen peroxide treatment, electrochemical reaction, and hydrothermal treatments, etc. improve the biocompatibility of the implant as well [143-145].

\section{(2) Directly filling the coating}

The surface of the implant can be coated with a bioactive material to facilitate bone tissue regeneration. As mentioned above, the surface is roughened by chemical surface modification, which is beneficial to the formation of the hydroxyapatite structure of a bone-like structure, thereby improving the osteogenesis ability of the implant. The same mechanism, the hydroxyapatite coating, directly modified the surface of the metal implant by plasma spraying method [146]. It can improve the biological function of the implant and promote the anchoring and healing performance of the bone tissue.

In addition to the surface-coated hydroxyapatite, bioactive materials coatings are also a replaceable choice. Stuebinger et al. [147] used the phosphoryl serine tethered dendrons as the surface coating for the implants. Animal experiments showed that the surface modification could promote osseointegration of the implant and increase the stability of the implant. Douglas et al. [148] coated pectin on the surface of titanium alloy bone scaffolds to promote the differentiation of bone marrow mesenchymal stem cells, thereby facilitating the cell growth and increasing the formation of hydroxyapatite, which can effectively reduce the local inflammation caused by the surface microbial growth. Moreover, studies have shown that $45 \mathrm{~S} 5$ bioglass can also be used for bio-coating [149]. Meanwhile, using polycrystalline diamond as a coating on the surface of the implant is also an efficient method to improve the biocompatibility of the implant. Rifai et al. [150] first applied chemical vapor deposition to apply the crystal diamond coating into the titanium alloy, which enriched the Ti-6Al-4V SLM biomedical implants application.

\section{(3) Using mechanical methods}

Metal implants manufactured by additive manufacturing, especially those obtained by the powder bed processing, have low surface quality and large surface porosity due to surface powder residue, which is not conducive to cell adhesion. What is worse, after the implantation, the powder shedding will adversely affect the human body. Therefore, it is necessary to ensure the surface quality of the implant by dealing with the surface powder remaining after processing [24].

Using mechanical methods like shot peening, ultrasonic, etc. can improve the surface quality of the implant. For example, Zebrowski et al. [151] used the shot peening method to modify the surface of the implant and explored the modification effect of different shots under different working pressures. The 
experimental results show that the appropriate process conditions can improve the surface quality of the implant and improve its microhardness and corrosion resistance. Furthermore, Bagherifard et al. [152] carried out surface characterization experiments, cell experiments and antibacterial experiments to systematically evaluate the effect of shot peening on the surface of implants from the characteristics of mechanical properties, cell function, and surface antibacterial properties. It has been found that blasting the implant surface promotes osseointegration, reducing the risk of bacterial infection and the resulting surgical complications. Moreover, as a novel surface modification technique, ultrasonic nano-crystal surface modification (UNSM) is safe, simple, and effective. It can improve the surface quality and decrease surface porosity without contact [153]. Hou et al. [154] applied UNSM to the surface modification of the implant and found that UNSM can improve the mechanical properties of the implant without affecting its biological function, which indicates the UNSM has a promising application on the implant.

Apart from the above methods, from the perspective of structural design, designing the surface microstructure for surface modification can enhance the bio-functionality of the implant surface. The microtopology designed on the surface of the implant can effectively reduce the adhesion of macrophages and fibroblasts, thus avoiding the inflammatory reaction when placed the implant into the human body [155]. Han et al. [156] studied the anti-cell adhesion properties of several different micro topologies. It was found that surface nanotexture technology improved the anti-cell viscosity of the implant surface and provided a new design for the surface modification of implants. Moreover, based on the mesoscale topological design, Weißmann et al. [157] proposed an open-cell structure on the surface of the acetabular cup. Pull-out and lever-out tests results showed that the surface-modified implant has better stability, which reveals that proper surface topology helps to improve the stability of the implant.

\section{Discussion and Future Development of AM Metallic Implants}

\subsection{Discussion}

The metallic additive manufacturing technology has developed rapidly. It is possible to obtain an implant whose outer contour is well matched to the bone defect region, and the implant can have the desired mechanical properties and physicochemical properties by adjusting the processing parameters during the manufacturing process. However, a series of problems, such as manufacturing time, cost, and precision, still need to be solved. For example, the minimum rod diameter the SLM can provide is around $0.2 \mathrm{~mm}$. This diameter compared with the actual internal fine structure of the human skeleton makes it quite difficult to restore a fractured bone using SLM. Moreover, various processing parameters, such as the scanning speed, the sintering energy density, etc., directly affect the final manufacturing effect. However, numerous processing research is still stuck in the study of the prototype. For a structurally variable implant, there is still not much attention. Therefore, it is necessary to explore the impact of processing methods on implants further and ensure the performance of the implant from a manufacturing perspective.

Using AM to process precious metals can effectively reduce errors, shorten preparation time, achieve the personalized design of products, and avoid manual errors. However, the current dental noble metal alloys processing in clinical application is mainly by casting. For new noble metal alloys, the casting precision cannot be promised, and the subsequent processing difficulty is increased, but the AM can effectively solve these problems. Nowadays, the processing of gold alloys, platinum alloys, and silver by AM has been realized in jewelry. Although there is no report on the AM of precious metal alloys in medicine, jewelry processing can be used for reference. Thus, the AM of noble metal alloys should be studied. Not only the preparation of various new precious metal alloy powders is required, but it is also critical to explore the process of the AM.

Moreover, applying various implant design methodologies to clinical application is still a challenge. In the past few decades, based on the defect bone anatomy data obtained by micro 
computed tomography (Micro-CT) or magnetic resonance imaging (MRI) technology, the porous structure designed to match the bone, especially the porous metal structure, has been successfully filled into the implant. Although good bone repair effect has been achieved, the complex internal tissue environment is often neglected in the theoretical design. As a result, the designed implant will encounter various uncertain factors during the operation. Additionally, additive manufacturing technology has not appeared for a long time, and the application of the design and fabrication of the implant is time-sensitive. There is a lack of long-term disease observation data to confirm the favorable therapeutic effect of the additive manufacturing of a metal implant. More practical clinical applications are needed to demonstrate the safety and clinical effect of metal implants.

\subsection{Future Development}

The implant undergoes a transition from a solid structure to a porous structure, and the porous implant also evolves from a periodic lattice structure to a biomimetic gradient structure. For bionic implants, the researchers carried out works in the aspects of material selection, structural design, and surface modification to restore the characteristics of natural bones, and obtained a series of biomimetic implants that meet the performance requirements of implants. However, limited by biomaterials, manufacturing factors, and structural characteristics, the performance of metal implants is still lacking. There is still a gap between the ideal implant and the current implant. Herein, we further discuss and conclude the development of metal implants in the future.

(1) New metallic biomaterials can improve the implant performance

In terms of material selection, bio-metal materials generally satisfy the biocompatibility of implants. Novel metal materials such as porous tantalum, shape memory alloys, and degradable metals are more similar to bones and are better implant materials. Among them, to make the implant have better toughness, the $\mathrm{Ni}-\mathrm{Ti}$ alloy can be used; however, the $\mathrm{Ni}$ ion contained therein may cause toxic effects on cells. Thus, referring to the idea of alloying to produce alloys, the powder bed processing technology is used to sinter the powders mixtures of different metals and obtain new implant materials, thereby eliminating the negative effects of toxic ions. Furthermore, to achieve the degradability of the implant, combining bioactive degradable metals (magnesium, zinc, etc.) with other metals with superior mechanical properties may bring more surprises.

Furthermore, with the help of PBF technology, it is possible to combine noble metals with other elements, which can improve the physicochemical property of noble alloys. For instance, adding some zinc powder to the gold powder when sintering can promise the machinability, which makes it possible to fabricate more superior samples. Mixing the iron to noble metals will contribute to the satisfactory mechanical properties, like the hardness and yield strength. Even some high-melting metals (iridium and rhodium) melt into gold to refine their microscopic crystals, which may form the alloy that has better adhesion with ceramics.

\section{(2) Biomimetic gradient structure can restore the characteristics of natural bone}

In terms of structural design, existing biomimetic implants achieve gradient changes in porosity and structural topology, but the internal structure of the bone is extremely complex, and the important porosity change law cannot be well restored. Moreover, the existing gradient structure cannot solve the problem of contact weakening between different layers. Therefore, we can select representative long bones, study the characteristics of natural bones, and then use the new modeling algorithm to design the biomimetic implant structure, which can better follow the changes in the porosity and topology of natural bone. Meanwhile, to realize the stable connection of different layers of the gradient structure, some connection strategies need to be studied. For example, the intermediate transition layer or the deformed existing structure topology can be established to accommodate the deviations of different layers. 
(3) The surface modification further enhances the biocompatibility of the implant

In terms of surface modification, different surface modification methods can form microstructures on the surface of the implant to promote bone cell growth or hydroxyapatite formation, but existing surface modification methods have little effect on the internal structure of the implant, and problems such as toxic ion release and bacterial infection cannot be properly solved. Therefore, novel surface modification techniques may be studied, for example, coating the surface of the implant with a new material (bioactive material encapsulating antibacterial particles). Additionally, further research on the antibacterial properties of the implant is needed to create an implant surface with biofunctionality and immunity.

\section{Conclusions}

Additive manufacturing technology provides the possibility for customized implants with complex structures to achieve personalized treatment of patients. This paper outlines the design and preparation process of metal implants, details the design method of implants, provides a broad examination of existing metal orthopedic implant, and describes further development trends in the future. In particular, the PBF technology enables the metal to be processed into a complicated structure, which enriches more degrees of freedom for designing a metal implant, thereby providing excellent properties for hard tissue replacement. Moreover, as the key technologies of the customized implant, the structural bionics and surface bio-functionalization will need to be further studied in the future. As a result, the clinical application of customized implants will be more extensive.

Author Contributions: L.B., X.C., and Y.S. conceptualized and designed the review; C.G., J.Z., and L.C. performed the collection of the literature; X.C., S.Z., L.C., and J.Z. analyzed the data; C.G., L.B., and X.C. wrote the paper. Y.S., S.Q.X., and X.C. carried out the review and editing. L.B. provided funding acquisition. All authors read and approved the manuscript.

Funding: This work was supported by the National Natural Science Foundation of China (Grant No. 51975070), Fundamental Research Funds for the Central Universities (Grant No. 2018CDGFJX0022 and 2019CDCGJX219).

Conflicts of Interest: The authors declare no conflict of interest.

\section{References}

1. Das, M.; Balla, V.K.; Kumar, T.S.; Manna, I. Fabrication of biomedical implants using laser engineered net shaping (LENS ${ }^{\mathrm{TM}}$ ). Trans. Indian Ceram. Soc. 2013, 72, 169-174. [CrossRef]

2. Larosa, M.A.; Jardini, A.L.; Zavaglia, C.A.D.C.; Kharmandayan, P.; Calderoni, D.R.; Maciel Filho, R. Microstructural and mechanical characterization of a custom-built implant manufactured in titanium alloy by direct metal laser sintering. Adv. Mech. Eng. 2014, 6, 945819. [CrossRef]

3. Chua, C.K.; Leong, K.F. 3D Printing and Additive Manufacturing: Principles and Applications (with Companion Media Pack) of Rapid Prototyping, 4th ed.; World Scientific Publishing Company: Singapur, Singapore, 2014.

4. Gibson, I. Advanced Manufacturing Technology for Medical Applications: Reverse Engineering, Software Conversion and Rapid Prototyping; John Wiley \& Sons: Hoboken, NJ, USA, 2006.

5. Huiskes, R.; Weinans, H.; Van Rietbergen, B. The relationship between stress shielding and bone resorption around total hip stems and the effects of flexible materials. Clin. Orthop. Rel. Res. 1992, 274, 124-134. [CrossRef]

6. Wieding, J.; Wolf, A.; Bader, R. Numerical optimization of open-porous bone scaffold structures to match the elastic properties of human cortical bone. J. Mech. Behav. Biomed. Mater. 2014, 37, 56-68. [CrossRef] [PubMed]

7. Ahmadi, S.; Yavari, S.; Wauthle, R.; Pouran, B.; Schrooten, J.; Weinans, H.; Zadpoor, A. Additively manufactured open-cell porous biomaterials made from six different space-filling unit cells: The mechanical and morphological properties. Materials 2015, 8, 1871-1896. [CrossRef] [PubMed]

8. Bobbert, F.S.L.; Lietaert, K.; Eftekhari, A.A.; Pouran, B.; Ahmadi, S.M.; Weinans, H.; Zadpoor, A.A. Additively manufactured metallic porous biomaterials based on minimal surfaces: A unique combination of topological, mechanical, and mass transport properties. Acta Biomater. 2017, 53, 572-584. [CrossRef] 
9. Onal, E.; Frith, J.E.; Jurg, M.; Wu, X.; Molotnikov, A. Mechanical Properties and in Vitro Behavior of Additively Manufactured and Functionally Graded Ti6Al4V Porous Scaffolds. Metals 2018, 8, 200. [CrossRef]

10. Song, C.-H. Study on Digital Design and Direct Manufacturing of Customized Implant Based on Selective Laser Melting. Ph.D. Thesis, South China University of Technology, Guangzhou, China, 2014.

11. Stoffelen, D.V.; Eraly, K.; Debeer, P. The use of 3D printing technology in reconstruction of a severe glenoid defect: A case report with 2.5 years of follow-up. J. Shoulder Elbow Surg. 2015, 24, e218-e222. [CrossRef]

12. Spetzger, U.; Frasca, M.; König, S.A. Surgical planning, manufacturing and implantation of an individualized cervical fusion titanium cage using patient-specific data. Eur. Spine J. 2016, 25, 2239-2246. [CrossRef]

13. Fan, H.; Fu, J.; Li, X.; Pei, Y.; Li, X.; Pei, G.; Guo, Z. Implantation of customized 3-D printed titanium prosthesis in limb salvage surgery: A case series and review of the literature. World J. Surg. Oncol. 2015, 13, 308. [CrossRef]

14. Utela, B.; Storti, D.; Anderson, R.; Ganter, M. A review of process development steps for new material systems in three dimensional printing (3DP). J. Manuf. Process. 2008, 10, 96-104. [CrossRef]

15. Guo, C.; Ge, W.; Lin, F. Effects of scanning parameters on material deposition during Electron Beam Selective Melting of Ti-6Al-4V powder. J. Manuf. Process. Technol. 2015, 217, 148-157. [CrossRef]

16. Basalah, A.; Esmaeili, S.; Toyserkani, E. On the influence of sintering protocols and layer thickness on the physical and mechanical properties of additive manufactured titanium porous bio-structures. J. Mater. Process. Technol. 2016, 238, 341-351. [CrossRef]

17. Yang, Y.; Lu, J.-B.; Luo, Z.-Y.; Wang, D. Accuracy and density optimization in directly fabricating customized orthodontic production by selective laser melting. Rapid Prototyp. J. 2012, 18, 482-489. [CrossRef]

18. Berretta, S.; Evans, K.; Ghita, O. Additive manufacture of PEEK cranial implants: Manufacturing considerations versus accuracy and mechanical performance. Mater. Des. 2018, 139, 141-152. [CrossRef]

19. Jande, Y.A.; Erdal, M.; Dag, S. Production of graded porous polyamide structures and polyamide-epoxy composites via selective laser sintering. J. Reinf. Plast. Compos. 2014, 33, 1017-1036. [CrossRef]

20. Miron-Borzan, C.S.; Dudescu, M.C.; Berce, P. Bending and compression tests for PA 2200 parts obtained using Selective Laser Sintering method. In Proceedings of the 4th International Conference on Computing and Solutions in Manufacturing Engineering 2016-CoSME'16, Braşov, Romania, 3-4 November 2016; Oancea, G., Dragoi, M.V., Eds.; EDP Sciences: Les Ulis, France, 2017; Volume 94, p. 03010.

21. Vanderesse, N.; Ky, I.; González, F.Q.; Nuño, N.; Bocher, P. Image analysis characterization of periodic porous materials produced by additive manufacturing. Mater. Des. 2016, 92, 767-778. [CrossRef]

22. Weißmann, V.; Bader, R.; Hansmann, H.; Laufer, N. Influence of the structural orientation on the mechanical properties of selective laser melted Ti6Al4V open-porous scaffolds. Mater. Des. 2016, 95, 188-197. [CrossRef]

23. Yavari, S.A.; van der Stok, J.; Ahmadi, S.; Wauthlé, R.; Schrooten, J.; Weinans, H.; Zadpoor, A. Mechanical analysis of a rodent segmental bone defect model: The effects of internal fixation and implant stiffness on load transfer. J. Biomech. 2014, 47, 2700-2708. [CrossRef]

24. Van Hooreweder, B.; Lietaert, K.; Neirinck, B.; Lippiatt, N.; Wevers, M. CoCr F75 scaffolds produced by additive manufacturing: Influence of chemical etching on powder removal and mechanical performance. J. Mech. Behav. Biomed. Mater. 2017, 70, 60-67. [CrossRef]

25. Ahn, Y.-K.; Kim, H.-G.; Park, H.-K.; Kim, G.-H.; Jung, K.-H.; Lee, C.-W.; Kim, W.-Y.; Lim, S.-H.; Lee, B.-S. Mechanical and microstructural characteristics of commercial purity titanium implants fabricated by electron-beam additive manufacturing. Mater. Lett. 2017, 187, 64-67. [CrossRef]

26. Mohammadhosseini, A.; Masood, S.; Fraser, D.; Jahedi, M. Dynamic compressive behaviour of Ti-6Al-4V alloy processed by electron beam melting under high strain rate loading. Adv. Manuf. 2015, 3, 232-243. [CrossRef]

27. Bandyopadhyay, A.; Krishna, B.V.; Xue, W.; Bose, S. Application of laser engineered net shaping (LENS) to manufacture porous and functionally graded structures for load bearing implants. J. Mater. Sci. Mater. Med. 2009, 20, 29. [CrossRef] [PubMed]

28. Bertol, L.S.; Júnior, W.K.; Silva, F.P.d.; Aumund-Kopp, C. Medical design: Direct metal laser sintering of Ti-6Al-4V. Mater. Des. 2010, 31, 3982-3988. [CrossRef]

29. George, N.; Nair, A.B. Porous tantalum: A new biomaterial in orthopedic surgery. In Fundamental Biomaterials: Metals; Elsevier: Amsterdam, The Netherlands, 2018; pp. 243-268.

30. Baltzer, N.; Copponnex, T. Properties and processing of precious metal alloys for biomedical applications. In Precious Metals for Biomedical Applications; Elsevier: Amsterdam, The Netherlands, 2014; pp. 3-36. 
31. Zhang, X.; Li, X.-W.; Li, J.-G.; Sun, X.-D. Preparation and mechanical property of a novel 3D porous magnesium scaffold for bone tissue engineering. Mater. Sci. Eng. C Mater. Biol. Appl. 2014, 42, 362-367. [CrossRef] [PubMed]

32. Demir, A.G.; Monguzzi, L.; Previtali, B. Selective laser melting of pure Zn with high density for biodegradable implant manufacturing. Addit. Manuf. 2017, 15, 20-28. [CrossRef]

33. Branemark, R.; Branemark, P.; Rydevik, B.; Myers, R.R. Osseointegration in skeletal reconstruction and rehabilitation: A review. J. Rehabil. Res. Dev. 2001, 38, 175-182.

34. Liu, X.; Chu, P.K.; Ding, C. Surface modification of titanium, titanium alloys, and related materials for biomedical applications. Mater. Sci. Eng. R Rep. 2004, 47, 49-121. [CrossRef]

35. Wang, D.; Wang, Y.; Wu, S.; Lin, H.; Yang, Y.; Fan, S.; Gu, C.; Wang, J.; Song, C. Customized a Ti6Al4V bone plate for complex pelvic fracture by selective laser melting. Materials 2017, 10, 35. [CrossRef]

36. Patel, N.R.; Gohil, P.P. A review on biomaterials: Scope, applications \& human anatomy significance. Int. J. Emerg. Technol. Adv. Eng. 2012, 2, 91-101.

37. Sumitomo, N.; Noritake, K.; Hattori, T.; Morikawa, K.; Niwa, S.; Sato, K.; Niinomi, M. Experiment study on fracture fixation with low rigidity titanium alloy. J. Mater. Sci. Mater. Med. 2008, 19, 1581-1586. [CrossRef] [PubMed]

38. Oldani, C.; Dominguez, A. Titanium as a Biomaterial for Implants. Recent Adv. Arthroplast. 2012, 218, 149-162.

39. Kobayashi, E.; Ando, M.; Tsutsumi, Y.; Doi, H.; Yoneyama, T.; Kobayashi, M.; Hanawa, T. Inhibition effect of zirconium coating on calcium phosphate precipitation of titanium to avoid assimilation with bone. Mater. Trans. 2007, 48, 301-306. [CrossRef]

40. Niinomi, M.; Nakai, M. Titanium-based biomaterials for preventing stress shielding between implant devices and bone. Int. J. Biomater. 2011, 2011, 10. [CrossRef] [PubMed]

41. Gjunter, V.; Sysoliatin, P.; Temerkhamor, T. Superelastic Shape Memory Implants in Maxillofacial Surgery, Traumatology, Orthopaedics and Neurosurgery; Tomsk University Publishing House: Tomsk, Russia, 1995; Volume 15.

42. Rahmanian, R.; Moghaddam, N.S.; Haberland, C.; Dean, D.; Miller, M.; Elahinia, M. Load Bearing and Stiffness Tailored NiTi Implants Produced by Additive Manufacturing: A Simulation Study; SPIE: Bellingham, WA, USA, 2014; Volume 9058.

43. Pawlak, A.; Szymczyk, P.; Ziolkowski, G.; Chlebus, E.; Dybala, B. Fabrication of microscaffolds from Ti-6Al-7Nb alloy by SLM. Rapid Prototyp. J. 2015, 21, 393-401. [CrossRef]

44. Szymczyk, P.; Ziółkowski, G.; Junka, A.; Chlebus, E. Application of Ti6Al7Nb alloy for the manufacture of Biomechanical Functional Structures (BFS) for custom-made bone implants. Materials 2018, 11, 971. [CrossRef] [PubMed]

45. Fischer, M.; Laheurte, P.; Acquier, P.; Joguet, D.; Peltier, L.; Petithory, T.; Anselme, K.; Mille, P. Synthesis and characterization of Ti-27.5 Nb alloy made by $\mathrm{CLAD}^{\circledR}$ additive manufacturing process for biomedical applications. Mater. Sci. Eng. C Mater. Biol. Appl. 2017, 75, 341-348. [CrossRef]

46. Schulze, C.; Weinmann, M.; Schweigel, C.; Keßler, O.; Bader, R. Mechanical properties of a newly additive manufactured implant material based on Ti-42Nb. Materials 2018, 11, 124. [CrossRef]

47. Alvarado, J.; Maldonado, R.; Marxuach, J.; Otero, R. Biomechanics of hip and knee prostheses. In Applications of Engineering Mechanics in Medicine; GED-University of Puerto Rico Mayaguez: Mayaguez, Puerto, 2003; pp. 1-20.

48. Stenlund, P.; Kurosu, S.; Koizumi, Y.; Suska, F.; Matsumoto, H.; Chiba, A.; Palmquist, A. Osseointegration enhancement by $\mathrm{Zr}$ doping of Co-Cr-Mo implants fabricated by electron beam melting. Addit. Manuf. 2015, 6, 6-15. [CrossRef]

49. Dewidar, M.M.; Khalil, K.A.; Lim, J. Processing and mechanical properties of porous 316L stainless steel for biomedical applications. Trans. Nonferr. Met. Soc. China 2007, 17, 468-473. [CrossRef]

50. Jandin, G.; Bertin, J.; Dembinski, L.; Coddet, C. Manufacture of stainless steel parts by selective laser melting process. In Proceedings of the 2nd International Conference on Advanced Research in Virtual and Rapid Prototyping, Leiria, Portugal, 28 September-1 October 2005; Taylor \& Francis Group: London, UK, 2005; pp. 431-434. 
51. Čapek, J.; Machova, M.; Fousova, M.; Kubásek, J.; Vojtěch, D.; Fojt, J.; Jablonska, E.; Lipov, J.; Ruml, T. Highly porous, low elastic modulus $316 \mathrm{~L}$ stainless steel scaffold prepared by selective laser melting. Mater. Sci. Eng. C Mater. Biol. Appl. 2016, 69, 631-639. [CrossRef] [PubMed]

52. Wehmöller, M.; Warnke, P.; Zilian, C.; Eufinger, H. Implant design and production-A new approach by selective laser melting. In Proceedings of the International Congress Series, Berlin, Germany, 22-25 June 2005; Elsevier: Amsterdam, The Netherlands, 2005; Volume 1281, pp. 690-695.

53. Perry, C. Biomaterials—A Tantalus experience. Mater. Today 2011, 14, 230. [CrossRef]

54. Levine, B.R.; Sporer, S.; Poggie, R.A.; Della Valle, C.J.; Jacobs, J.J. Experimental and clinical performance of porous tantalum in orthopedic surgery. Biomaterials 2006, 27, 4671-4681. [CrossRef] [PubMed]

55. Sungail, C.; Abid, A. Spherical tantalum feed powder for metal additive manufacturing. Met. Powder Rep. 2018, 73, 316-318. [CrossRef]

56. Wauthle, R.; Van Der Stok, J.; Yavari, S.A.; Van Humbeeck, J.; Kruth, J.-P.; Zadpoor, A.A.; Weinans, H.; Mulier, M.; Schrooten, J. Additively manufactured porous tantalum implants. Acta Biomater. 2015, 14, 217-225. [CrossRef] [PubMed]

57. Givan, D.A. Precious metals in dentistry. Dent. Clin. N. Am. 2007, 51, 591-601. [CrossRef]

58. Wataha, J.C. Alloys for prosthodontic restorations. J. Prosthet. Dent. 2002, 87, 351-363. [CrossRef] [PubMed]

59. Cart, A.B.; Brantley, W.A. New High-Palladium Casting Alloys: Part 1. Overview and Initial Studies. Int. J. Prosthodont. 1991, 4, 265-275.

60. Berzins, D.; Kawashima, I.; Graves, R.; Sarkar, N. Heat treatment effects on electrochemical corrosion parameters of high-Pd alloys. J. Mater. Sci. Mater. Med. 2008, 19, 335-341. [CrossRef]

61. Garau, V.; Masala, M.G.; Cortis, M.C.; Pittau, R. Contact stomatitis due to palladium in dental alloys: A clinical report. J. Prosthet. Dent. 2005, 93, 318-320. [CrossRef]

62. Muris, J.; Feilzer, A.; Rustemeyer, T.; Kleverlaan, C. Palladium allergy prevalence is underestimated because of an inadequate test allergen. Contact Dermat. 2011, 65, 62. [CrossRef]

63. Givan, D. Precious metal alloys for dental applications. In Precious Metals for Biomedical Applications; Elsevier: Amsterdam, The Netherlands, 2014; pp. 109-129.

64. Kaminski, R.A.; Anusavice, K.; Okabe, T.; Morse, P.; Casteel, P. Castability of silver-base fixed partial denture alloys. J. Prosthet. Dent. 1985, 53, 329-332. [CrossRef]

65. Revell, P.A.; Damien, E.; Zhang, X.; Evans, P.; Howlett, C.R. The effect of magnesium ions on bone bonding to hydroxyapatite coating on titanium alloy implants. In Key Engineering Materials, Proceedings of the 16th International Symposium on Ceramics in Medicine, Porto, Portugal, 6-9 November 2003; Trans Tech Publications: Zürich, Switzerland, 2004; Volume 254, pp. 447-450.

66. Janning, C.; Willbold, E.; Vogt, C.; Nellesen, J.; Meyer-Lindenberg, A.; Windhagen, H.; Thorey, F.; Witte, F. Magnesium hydroxide temporarily enhancing osteoblast activity and decreasing the osteoclast number in peri-implant bone remodelling. Acta Biomater. 2010, 6, 1861-1868. [CrossRef] [PubMed]

67. Chung Ng, C.; Savalani, M.; Chung Man, H. Fabrication of magnesium using selective laser melting technique. Rapid Prototyp. J. 2011, 17, 479-490. [CrossRef]

68. Li, Y.; Zhou, J.; Pavanram, P.; Leeflang, M.A.; Fockaert, L.I.; Pouran, B.; Tümer, N.; Schröder, K.U.; Mol, J.M.C.; Weinans, H.; et al. Additively manufactured biodegradable porous magnesium. Acta Biomater. 2018, 67, 378-392. [CrossRef] [PubMed]

69. Peng, Q.; Huang, Y.; Zhou, L.; Hort, N.; Kainer, K.U. Preparation and properties of high purity Mg-Y biomaterials. Biomaterials 2010, 31, 398-403. [CrossRef] [PubMed]

70. Hort, N.; Huang, Y.; Fechner, D.; Störmer, M.; Blawert, C.; Witte, F.; Vogt, C.; Drücker, H.; Willumeit, R.; Kainer, K. Magnesium alloys as implant materials-Principles of property design for Mg-RE alloys. Acta Biomater. 2010, 6, 1714-1725. [CrossRef] [PubMed]

71. Jin, W.; Wu, G.; Gao, A.; Feng, H.; Peng, X.; Chu, P.K. Hafnium-implanted WE43 magnesium alloy for enhanced corrosion protection and biocompatibility. Surf. Coat. Technol. 2016, 306, 11-15. [CrossRef]

72. Kraus, T.; Moszner, F.; Fischerauer, S.; Fiedler, M.; Martinelli, E.; Eichler, J.; Witte, F.; Willbold, E.; Schinhammer, M.; Meischel, M. Biodegradable Fe-based alloys for use in osteosynthesis: Outcome of an in vivo study after 52 weeks. Acta Biomater. 2014, 10, 3346-3353. [CrossRef]

73. Li, Y.; Jahr, H.; Lietaert, K.; Pavanram, P.; Yilmaz, A.; Fockaert, L.; Leeflang, M.; Pouran, B.; Gonzalez-Garcia, Y.; Weinans, H. Additively manufactured biodegradable porous iron. Acta Biomater. 2018, 77, 380-393. [CrossRef] 
74. Francis, A.; Yang, Y.; Virtanen, S.; Boccaccini, A. Iron and iron-based alloys for temporary cardiovascular applications. J. Mater. Sci. Mater. Med. 2015, 26, 138. [CrossRef] [PubMed]

75. He, J.; He, F.-L.; Li, D.-W.; Liu, Y.-L.; Liu, Y.-Y.; Ye, Y.-J.; Yin, D.-C. Advances in Fe-based biodegradable metallic materials. RSC Adv. 2016, 6, 112819-112838. [CrossRef]

76. Hermawan, H. Updates on the research and development of absorbable metals for biomedical applications. Prog. Biomater. 2018, 7, 93-110. [CrossRef] [PubMed]

77. Wen, P.; Voshage, M.; Jauer, L.; Chen, Y.; Qin, Y.; Poprawe, R.; Schleifenbaum, J.H. Laser additive manufacturing of $\mathrm{Zn}$ metal parts for biodegradable applications: Processing, formation quality and mechanical properties. Mater. Des. 2018, 155, 36-45. [CrossRef]

78. Wen, P.; Jauer, L.; Voshage, M.; Chen, Y.; Poprawe, R.; Schleifenbaum, J.H. Densification behavior of pure Zn metal parts produced by selective laser melting for manufacturing biodegradable implants. J. Mater. Process. Technol. 2018, 258, 128-137. [CrossRef]

79. Mostaed, E.; Sikora-Jasinska, M.; Mostaed, A.; Loffredo, S.; Demir, A.; Previtali, B.; Mantovani, D.; Beanland, R.; Vedani, M. Novel Zn-based alloys for biodegradable stent applications: Design, development and in vitro degradation. J. Mech. Behav. Biomed. Mater. 2016, 60, 581-602. [CrossRef] [PubMed]

80. Tang, Z.; Huang, H.; Niu, J.; Zhang, L.; Zhang, H.; Pei, J.; Tan, J.; Yuan, G. Design and characterizations of novel biodegradable $\mathrm{Zn}-\mathrm{Cu}-\mathrm{Mg}$ alloys for potential biodegradable implants. Mater. Des. 2017, 117, 84-94. [CrossRef]

81. Katarivas Levy, G.; Goldman, J.; Aghion, E. The prospects of zinc as a structural material for biodegradable implants-A review paper. Metals 2017, 7, 402. [CrossRef]

82. Béreš, M.; Silva, C.; Sarvezuk, P.; Wu, L.; Antunes, L.; Jardini, A.; Feitosa, A.; Žilková, J.; de Abreu, H. Mechanical and phase transformation behaviour of biomedical Co-Cr-Mo alloy fabricated by direct metal laser sintering. Mater. Sci. Eng. A Struct. Mater. Prop. Microstruct. Process. 2018, 714, 36-42. [CrossRef]

83. Cowley, A. A healthy future: platinum in medical applications. Platin. Met. Rev. 2011, 55, 98-107. [CrossRef]

84. Wataha, J.C.; Shor, K. Palladium alloys for biomedical devices. Expert Rev. Med. Devices 2010, 7, 489-501. [CrossRef] [PubMed]

85. Avedesian, M.M.; Baker, H. ASM Specialty Handbook: Magnesium and Magnesium Alloys; ASM International: Geauga County, OH, USA, 1999.

86. Chmelik, F.; Trojanova, Z.; Lukáč, P.; Převorovský, Z. Acoustic emission from zinc deformed at room temperature Part I The influence of strain rate on deformation behaviour and acoustic emission in pure zinc. J. Mater. Sci. Lett. 1993, 12, 1086-1087. [CrossRef]

87. Radovan, H.; Jozef, Ž.; Teodor, T.; Jaroslav, M.; Martin, L. Evaluation of custom-made implants using industrial computed tomography. In Proceedings of the 10th International Conference on Digital Technologies, Zilina, Slovakia, 9-11 July 2014; pp. 82-86.

88. Wubneh, A.; Tsekoura, E.; Ayranci, C.; Uludağ, H. Current state of fabrication technologies and materials for bone tissue engineering. Acta Biomater. 2018, 80, 1-30. [CrossRef] [PubMed]

89. Zadpoor, A.A. Bone tissue regeneration: The role of scaffold geometry. Biomater. Sci. 2015, 3, $231-245$. [CrossRef] [PubMed]

90. Karageorgiou, V.; Kaplan, D. Porosity of 3D biomaterial scaffolds and osteogenesis. Biomaterials 2005, 26, 5474-5491. [CrossRef] [PubMed]

91. Campoli, G.; Weinans, H.; Zadpoor, A.A. Computational load estimation of the femur. J. Mech. Behav. Biomed. Mater. 2012, 10, 108-119. [CrossRef] [PubMed]

92. Van Bael, S.; Chai, Y.C.; Truscello, S.; Moesen, M.; Kerckhofs, G.; Van Oosterwyck, H.; Kruth, J.-P.; Schrooten, J. The effect of pore geometry on the in vitro biological behavior of human periosteum-derived cells seeded on selective laser-melted Ti6Al4V bone scaffolds. Acta Biomater. 2012, 8, 2824-2834. [CrossRef]

93. Cheng, A.; Humayun, A.; Cohen, D.J.; Boyan, B.D.; Schwartz, Z. Additively manufactured 3D porous Ti-6Al-4V constructs mimic trabecular bone structure and regulate osteoblast proliferation, differentiation and local factor production in a porosity and surface roughness dependent manner. Biofabrication 2014, 6, 045007. [CrossRef]

94. Maskery, I.; Aremu, A.O.; Simonelli, M.; Tuck, C.; Wildman, R.D.; Ashcroft, I.A.; Hague, R.J.M. Mechanical Properties of Ti-6Al-4V Selectively Laser Melted Parts with Body-Centred-Cubic Lattices of Varying cell size. Exp. Mech. 2015, 55, 1261-1272. [CrossRef] 
95. Rodríguez-Montaño, Ó.L.; Cortés-Rodríguez, C.J.; Uva, A.E.; Fiorentino, M.; Gattullo, M.; Monno, G.; Boccaccio, A. Comparison of the mechanobiological performance of bone tissue scaffolds based on different unit cell geometries. J. Mech. Behav. Biomed. Mater. 2018, 83, 28-45. [CrossRef]

96. Mazur, M.; Leary, M.; Sun, S.; Vcelka, M.; Shidid, D.; Brandt, M. Deformation and failure behaviour of Ti-6Al-4V lattice structures manufactured by selective laser melting (SLM). Int. J. Adv. Manuf. Technol. 2016, 84, 1391-1411. [CrossRef]

97. Xu, Y.; Zhang, D.; Zhou, Y.; Wang, W.; Cao, X. Study on topology optimization design, manufacturability, and performance evaluation of Ti-6Al-4V porous structures fabricated by selective laser melting (SLM). Materials 2017, 10, 1048.

98. Chantarapanich, N.; Puttawibul, P.; Sucharitpwatskul, S.; Jeamwatthanachai, P.; Inglam, S.; Sitthiseripratip, K. Scaffold library for tissue engineering: A geometric evaluation. Comput. Math. Method Med. 2012, $2012,14$. [CrossRef] [PubMed]

99. Bucklen, B.S.; Wettergreen, W.A.; Yuksel, E.; Liebschner, M.A.K. Bone-derived CAD library for assembly of scaffolds in computer-aided tissue engineering. Virtual. Phys. Prototy. 2008, 3, 13-23. [CrossRef]

100. Ushijima, K.; Cantwell, W.J.; Mines, R.A.W.; Tsopanos, S.; Smith, M. An investigation into the compressive properties of stainless steel micro-lattice structures. J. Sandw. Struct. Mater. 2011, 13, 303-329. [CrossRef]

101. Zhang, M.; Yang, Z.; Lu, Z.; Liao, B.; He, X. Effective elastic properties and initial yield surfaces of two 3D lattice structures. Int. J. Mech. Sci. 2018, 138, 146-158. [CrossRef]

102. Ahmadi, S.M.; Campoli, G.; Yavari, S.A.; Sajadi, B.; Wauthle, R.; Schrooten, J.; Weinans, H.; Zadpoor, A.A. Mechanical behavior of regular open-cell porous biomaterials made of diamond lattice unit cells. J. Mech. Behav. Biomed. Mater. 2014, 34, 106-115. [CrossRef]

103. Wang, H.; Su, K.; Su, L.; Liang, P.; Ji, P.; Wang, C. The effect of 3D-printed Ti6Al4V scaffolds with various macropore structures on osteointegration and osteogenesis: A biomechanical evaluation. J. Mech. Behav. Biomed. Mater. 2018, 88, 488-496. [CrossRef]

104. Choy, S.Y.; Sun, C.-N.; Leong, K.F.; Wei, J. Compressive properties of Ti-6Al-4V lattice structures fabricated by selective laser melting: Design, orientation and density. Addit. Manuf. 2017, 16, 213-224. [CrossRef]

105. Guo, X.-F.; Ma, L. Periodic topological lattice with different indentation hardness on opposite surfaces. Mater. Des. 2019, 180, 107953. [CrossRef]

106. Reznikov, N.; Chase, H.; Zvi, Y.B.; Tarle, V.; Singer, M.; Brumfeld, V.; Shahar, R.; Weiner, S. Inter-trabecular angle: A parameter of trabecular bone architecture in the human proximal femur that reveals underlying topological motifs. Acta Biomater. 2016, 44, 65-72. [CrossRef] [PubMed]

107. Jetté, B.; Brailovski, V.; Dumas, M.; Simoneau, C.; Terriault, P. Femoral stem incorporating a diamond cubic lattice structure: Design, manufacture and testing. J. Mech. Behav. Biomed. Mater. 2018, 77, 58-72. [CrossRef] [PubMed]

108. Liu, F.; Zhang, D.Z.; Zhang, P.; Zhao, M.; Jafar, S. Mechanical Properties of Optimized Diamond Lattice Structure for Bone Scaffolds Fabricated via Selective Laser Melting. Materials 2018, 11, 374. [CrossRef] [PubMed]

109. Soro, N.; Attar, H.; Wu, X.; Dargusch, M.S. Investigation of the structure and mechanical properties of additively manufactured Ti-6Al-4V biomedical scaffolds designed with a Schwartz primitive unit-cell. Mater. Sci. Eng. A Struct. Mater. Prop. Microstruct. Process. 2019, 745, 195-202. [CrossRef]

110. Ataee, A.; Li, Y.; Fraser, D.; Song, G.; Wen, C. Anisotropic Ti-6Al-4V gyroid scaffolds manufactured by electron beam melting (EBM) for bone implant applications. Mater. Des. 2018, 137, 345-354. [CrossRef]

111. Ataee, A.; Li, Y.; Brandt, M.; Wen, C. Ultrahigh-strength titanium gyroid scaffolds manufactured by selective laser melting (SLM) for bone implant applications. Acta Mater. 2018, 158, 354-368. [CrossRef]

112. Yoo, D.J. Porous scaffold design using the distance field and triply periodic minimal surface models. Biomaterials 2011, 32, 7741-7754. [CrossRef] [PubMed]

113. Al-Ketan, O.; Abu Al-Rub, R.K.; Rowshan, R. Mechanical Properties of a New Type of Architected Interpenetrating Phase Composite Materials. Adv. Mater. Technol. 2017, 2, 1600235. [CrossRef]

114. Al-Ketan, O.; Rowshan, R.; Abu Al-Rub, R.K. Topology-mechanical property relationship of 3D printed strut, skeletal, and sheet based periodic metallic cellular materials. Addit. Manuf. 2018, 19, 167-183. [CrossRef]

115. Yang, L.; Yan, C.; Han, C.; Chen, P.; Yang, S.; Shi, Y. Mechanical response of a triply periodic minimal surface cellular structures manufactured by selective laser melting. Int. J. Mech. Sci. 2018, 148, 149-157. [CrossRef] 
116. Tang, Y.; Kurtz, A.; Zhao, Y.F. Bidirectional Evolutionary Structural Optimization (BESO) based design method for lattice structure to be fabricated by additive manufacturing. Comput. Aided Des. 2015, 69, 91-101. [CrossRef]

117. Zegard, T.; Paulino, G.H. Bridging topology optimization and additive manufacturing. Struct. Multidiscip. Optim. 2016, 53, 175-192. [CrossRef]

118. Maheshwaraa Namasivayam, U.; Conner Seepersad, C. Topology design and freeform fabrication of deployable structures with lattice skins. Rapid Prototyp. J. 2011, 17, 5-16. [CrossRef]

119. Huang, X.; Xie, Y. Bidirectional Evolutionary Topology Optimization for Structures with Geometrical and Material Nonlinearities. AIAA J. 2006, 45, 308-313. [CrossRef]

120. Huang, X.; Radman, A.; Xie, Y. Topological design of microstructures of cellular materials for maximum bulk or shear modulus. Comput. Mater. Sci. 2011, 50, 1861-1870.

121. Burblies, A.; Busse, M. Computer based porosity design by multi phase topology optimization. In Multiscale and Functionally Graded Materials, Oahu Island, HI, USA, 15-18 October 2006; Paulino, G.H., Pindera, M.J., Dodds, R.H., Rochinha, F.A., Dave, E.V., Chen, L., Eds.; American Institute of Physics: College Park, MD, USA, 2008; Volume 973, pp. 285-290.

122. Surmeneva, M.A.; Surmenev, R.A.; Chudinova, E.A.; Koptioug, A.; Tkachev, M.S.; Gorodzha, S.N.; Rännar, L.-E. Fabrication of multiple-layered gradient cellular metal scaffold via electron beam melting for segmental bone reconstruction. Mater. Des. 2017, 133, 195-204. [CrossRef]

123. Choy, S.Y.; Sun, C.-N.; Leong, K.F.; Wei, J. Compressive properties of functionally graded lattice structures manufactured by selective laser melting. Mater. Des. 2017, 131, 112-120. [CrossRef]

124. Liu, F.; Mao, Z.; Zhang, P.; Zhang, D.Z.; Jiang, J.; Ma, Z. Functionally graded porous scaffolds in multiple patterns: New design method, physical and mechanical properties. Mater. Des. 2018, 160, 849-860. [CrossRef]

125. Li, S.; Zhao, S.; Hou, W.; Teng, C.; Hao, Y.; Li, Y.; Yang, R.; Misra, R.D.K. Functionally Graded Ti-6Al-4V Meshes with High Strength and Energy Absorption. Adv. Eng. Mater. 2015, 18, 34-38. [CrossRef]

126. Chung, H.; Das, S. Functionally graded Nylon-11/silica nanocomposites produced by selective laser sintering. Mater. Sci. Eng. A Struct. Mater. Prop. Microstruct. Process. 2008, 487, 251-257. [CrossRef]

127. Dumas, M.; Terriault, P.; Brailovski, V. Modelling and characterization of a porosity graded lattice structure for additively manufactured biomaterials. Mater. Des. 2017, 121, 383-392. [CrossRef]

128. Zhang, X.-Y.; Fang, G.; Xing, L.-L.; Liu, W.; Zhou, J. Effect of porosity variation strategy on the performance of functionally graded Ti-6Al-4V scaffolds for bone tissue engineering. Mater. Des. 2018, 157, 523-538. [CrossRef]

129. Zhang, X.-Y.; Fang, G.; Leeflang, S.; Zadpoor, A.A.; Zhou, J. Topological design, permeability and mechanical behavior of additively manufactured functionally graded porous metallic biomaterials. Acta Biomater. 2019, 84, 437-452. [CrossRef] [PubMed]

130. Maskery, I.; Aremu, A.O.; Parry, L.; Wildman, R.D.; Tuck, C.J.; Ashcroft, I.A. Effective design and simulation of surface-based lattice structures featuring volume fraction and cell type grading. Mater. Des. 2018, 155, 220-232. [CrossRef]

131. Vijayavenkataraman, S.; Lei, Z.; Zhang, S.; Fuh, J.Y.H.; Wen, F.L. Triply Periodic Minimal Surfaces Sheet Scaffolds for Tissue Engineering Applications: An Optimization Approach towards Biomimetic Scaffold Design. ACS Appl. Bio Mater. 2018, 1, 259-269. [CrossRef]

132. Yoo, D.J. Heterogeneous porous scaffold design for tissue engineering using triply periodic minimal surfaces. Int. J. Precis. Eng. Manuf. 2012, 13, 527-537. [CrossRef]

133. Han, C.; Li, Y.; Wang, Q.; Wen, S.; Wei, Q.; Yan, C.; Hao, L.; Liu, J.; Shi, Y. Continuous functionally graded porous titanium scaffolds manufactured by selective laser melting for bone implants. J. Mech. Behav. Biomed. Mater. 2018, 80, 119-127. [CrossRef]

134. Yang, L.; Mertens, R.; Ferrucci, M.; Yan, C.; Shi, Y.; Yang, S. Continuous graded Gyroid cellular structures fabricated by selective laser melting: Design, manufacturing and mechanical properties. Mater. Des. 2019, 162, 394-404. [CrossRef]

135. Afshar, M.; Anaraki, A.P.; Montazerian, H. Compressive characteristics of radially graded porosity scaffolds architectured with minimal surfaces. Mater. Sci. Eng. C Mater. Biol. Appl. 2018, 92, 254-267. [CrossRef]

136. Feng, J.W.; Fu, J.Z.; Shang, C.; Lin, Z.W.; Li, B. Porous scaffold design by solid T-splines and triply periodic minimal surfaces. Comput. Meth. Appl. Mech. Eng. 2018, 336, 333-352. [CrossRef] 
137. Sudarmadji, N.; Tan, J.Y.; Leong, K.F.; Chua, C.K.; Loh, Y.T. Investigation of the mechanical properties and porosity relationships in selective laser-sintered polyhedral for functionally graded scaffolds. Acta Biomater. 2011, 7, 530-537. [CrossRef] [PubMed]

138. Torres, Y.; Trueba, P.; Pavon, J.J.; Chicardi, E.; Kamm, P.; Garcia-Moreno, F.; Rodriguez-Ortiz, J.A. Design, processing and characterization of titanium with radial graded porosity for bone implants. Mater. Des. 2016, 110, 179-187. [CrossRef]

139. Svehla, M.; Morberg, P.; Zicat, B.; Bruce, W.; Sonnabend, D.; Walsh, W.R. Morphometric and mechanical evaluation of titanium implant integration: Comparison of five surface structures. J. Biomed. Mater. Res. Part B 2000, 51, 15-22. [CrossRef]

140. Heinl, P.; Müller, L.; Körner, C.; Singer, R.F.; Müller, F.A. Cellular Ti-6Al-4V structures with interconnected macro porosity for bone implants fabricated by selective electron beam melting. Acta Biomater. 2008, 4, 1536-1544. [CrossRef] [PubMed]

141. Korobkova, A.; Kazakbiev, A.; Zhukova, Y.; Sheremetyev, V.; Dubinskiy, S.; Filonov, M. Surface treatment of bulk and porous materials based on superelastic titanium alloys for medical implants. Mater. Today Proc. 2017, 4, 4664-4669. [CrossRef]

142. Yavari, S.A.; van der Stok, J.; Chai, Y.C.; Wauthle, R.; Birgani, Z.T.; Habibovic, P.; Mulier, M.; Schrooten, J.; Weinans, H.; Zadpoor, A.A. Bone regeneration performance of surface-treated porous titanium. Biomaterials 2014, 35, 6172-6181. [CrossRef] [PubMed]

143. Larsson Wexell, C.; Thomsen, P.; Aronsson, B.-O.; Tengvall, P.; Rodahl, M.; Lausmaa, J.; Kasemo, B.; Ericson, L. Bone response to surface-modified titanium implants: Studies on the early tissue response to implants with different surface characteristics. Int. J. Biomater. 1996, 17, 605-616. [CrossRef]

144. Li, G.; Cao, H.; Zhang, W.; Ding, X.; Yang, G.; Qiao, Y.; Liu, X.; Jiang, X. Enhanced osseointegration of hierarchical micro/nanotopographic titanium fabricated by microarc oxidation and electrochemical treatment. ACS Appl. Mater. Interfaces 2016, 8, 3840-3852. [CrossRef]

145. Shi, X.; Nakagawa, M.; Kawachi, G.; Xu, L.; Ishikawa, K. Surface modification of titanium by hydrothermal treatment in Mg-containing solution and early osteoblast responses. J. Mater. Sci. Mater. Med. 2012, 23, 1281-1290. [CrossRef] [PubMed]

146. Lindahl, C.; Xia, W.; Engqvist, H.; Snis, A.; Lausmaa, J.; Palmquist, A. Biomimetic calcium phosphate coating of additively manufactured porous CoCr implants. Appl. Surf. Sci. 2015, 353, 40-47. [CrossRef]

147. Stuebinger, S.; Nuss, K.; Buerki, A.; Mosch, I.; le Sidler, M.; Meikle, S.T.; von Rechenberg, B.; Santin, M. Osseointegration of titanium implants functionalised with phosphoserine-tethered poly(epsilon-lysine) dendrons: A comparative study with traditional surface treatments in sheep. J. Mater. Sci. Mater. Med. 2015, 26, 87. [CrossRef] [PubMed]

148. Douglas, T.E.L.; Hempel, U.; Zydek, J.; Vladescu, A.; Pietryga, K.; Kaeswurm, J.A.H.; Buchweitz, M.; Surmenev, R.A.; Surmeneva, M.A.; Cotrut, C.M.; et al. Pectin coatings on titanium alloy scaffolds produced by additive manufacturing: Promotion of human bone marrow stromal cell proliferation. Mater. Lett. 2018, 227, 225-228. [CrossRef]

149. Dominguez-Trujillo, C.; Ternero, F.; Antonio Rodriguez-Ortiz, J.; Jose Pavon, J.; Montealegre-Melendez, I.; Arevalo, C.; Garcia-Moreno, F.; Torres, Y. Improvement of the balance between a reduced stress shielding and bone rit ingrowth by bioactive coatings onto porous titanium substrates. Surf. Coat. Technol. 2018, 338, 32-37. [CrossRef]

150. Rifai, A.; Nhiem, T.; Lau, D.W.; Elbourne, A.; Zhan, H.; Stacey, A.D.; Mayes, E.L.H.; Sarker, A.; Ivanova, E.P.; Crawford, R.J.; et al. Polycrystalline Diamond Coating of Additively Manufactured Titanium for Biomedical Applications. ACS Appl. Mater. Interfaces 2018, 10, 8474-8484. [CrossRef] [PubMed]

151. Zebrowski, R.; Walczak, M.; Klepka, T.; Pasierbiewicz, K. Effect of the shot peening on surface properties of ti-6al-4v alloy produced by means of DMLS technology. Eksploat. Niezawodn. 2019, 21, 46-53. [CrossRef]

152. Bagherifard, S.; Hickey, D.J.; de Luca, A.C.; Malheiro, V.N.; Markaki, A.E.; Guagliano, M.; Webster, T.J. The influence of nanostructured features on bacterial adhesion and bone cell functions on severely shot peened 316L stainless steel. Biomaterials 2015, 73, 185-197. [CrossRef] [PubMed]

153. Ma, C.; Andani, M.T.; Qin, H.; Moghaddam, N.S.; Ibrahim, H.; Jahadakbar, A.; Amerinatanzi, A.; Ren, Z.; Zhang, H.; Doll, G.L.; et al. Improving surface finish and wear resistance of additive manufactured nickel-titanium by ultrasonic nano-crystal surface modification. J. Mater. Process. Technol. 2017, 249, 433-440. [CrossRef] 
154. Hou, X.; Qin, H.; Gao, H.; Mankoci, S.; Zhang, R.; Zhou, X.; Ren, Z.; Doll, G.L.; Martini, A.; Sahai, N. A systematic study of mechanical properties, corrosion behavior and biocompatibility of AZ31B Mg alloy after ultrasonic nanocrystal surface modification. Mater. Sci. Eng. C Mater. Biol. Appl. 2017, 78, 1061-1071. [CrossRef]

155. Robotti, F.; Bottan, S.; Fraschetti, F.; Mallone, A.; Pellegrini, G.; Lindenblatt, N.; Starck, C.; Falk, V.; Poulikakos, D.; Ferrari, A. A micron-scale surface topography design reducing cell adhesion to implanted materials. Sci. Rep. 2018, 8, 10887. [CrossRef]

156. Han, E.D.; Kim, B.H.; Seo, Y.H. Anti-cell adhesion characteristics of nanotextured surface for implantable biomedical device. Int. J. Precis. Eng. Manuf. 2017, 18, 239-244. [CrossRef]

157. Weißmann, V.; Boss, C.; Bader, R.; Hansmann, H. A novel approach to determine primary stability of acetabular press-fit cups. J. Mech. Behav. Biomed. Mater. 2018, 80,1-10. [CrossRef] [PubMed]

C 2019 by the authors. Licensee MDPI, Basel, Switzerland. This article is an open access article distributed under the terms and conditions of the Creative Commons Attribution (CC BY) license (http://creativecommons.org/licenses/by/4.0/). 